

\title{
The Diaristic Mode in Contemporary Art after Barthes
}

\author{
Margaret Iversen
}

Detail of Moyra Davey, Bulbs, 2014 (plate 4).

DOI:

10.1111//467-8365.12587

Art History| ISSN 0I4I-6790

$X X|X|$ Month $X X X X \mid$ pages

$X X-X X$
Roland Barthes's influential essay, 'The Death of the Author', was a critique of the elevation of the idea of the author in modern times. While Barthes acknowledged that certain writers, such as Stéphane Mallarmé, had attempted to topple the author's dominant position, he observed that the image of literature was still centred on "his person, his history, his tastes, his passions.' 'The Death of the Author' was originally published in the 1967 issue of the art magazine Aspen, edited by Brian O'Doherty and dedicated to Mallarmé. It contained works aimed at eliminating subjectivity, such as Sol LeWitt's Serial Project \#1 (1966). ${ }^{2}$ Barthes's call for authorial renunciation captured the tenor of the times, and apparently ruled out any autobiographical or diaristic art practice: the diary form, above all genres, would seem to assume a fully present, expressive self. Yet some artists, working within and in the wake of minimal and conceptual art, nevertheless pursued diary-like art practices. ${ }^{3}$ These artists were mirroring Barthes's own gradual conversion to a diaristic mode of writing. He had for some time been turning away from scientific, semiological discourses, and toward something far more literary and intimate. His fragmentary autobiography, Roland Barthes by Roland Barthes (1975), although written in the third person, was indicative of this shift. When Camera Lucida was published in 1980, it became clear that he had abandoned the ideal of an 'objective', impersonal writing degree zero and had exchanged Mallarmé for Marcel Proust.

Barthes started keeping a diary the day after his mother's death on 25 October 1977. When Mourning Diary was published thirty years after his death, in 2009, it precipitated much discussion amongst literary critics of the possibility of a new kind of fragmentary, diaristic novel, and a new conception of the author's role. ${ }^{4}$ Barthes himself had frequently ruminated on the subject in lectures and seminars. In 1978, he published a lecture on Proust entitled 'Longtemps, je me suis couché de bonne heure ...' ('For a long time, I used to go to bed early') which is the opening sentence of In Search of Lost Time. Barthes suggested that Proust's novel, written after the death of his mother, was an original literary form devised to accommodate the author's suffering, and he regarded it as a possible model for his own effort to combine the genres of essay, novel, and diaristic notation. For Barthes, Proust's first-person narrator, 'Marcel', is not a substantive autobiographical subject who relates a chronological history; rather, 'the person this "I" brings on stage is a writing self'. Barthes invents this figure of the 'writing self' as a way of evading both the egoism of autobiography and the arrogance of theory: 'It is the intimate which seeks utterance in me, seeks to make its cry heard, confronting generality, confronting science.' 'Longtemps' closes with an allusion to 
Dante's Inferno. Barthes's bereavement marked for him 'the middle of life's journey', where a path would lead out of the 'dark wood' of his grief and inaugurate what he hoped would be a vita nova. His 'new life', sadly cut short, would involve, above all, a new practice of writing. ${ }^{5}$

The problems inherent in the diary as a 'proper' literary genre are exacerbated in diaries concerning mourning. In the first place, narrative, which renders a book coherent, is incompatible with mourning. As Antoine Compagnon has explained, this is so because 'yielding to narrative, to literature, would mean refusing, avoiding, or denying mourning.' 'The slip of paper, the note, the brief record of emotion, are pure repetitions of an instant. They refuse to be inscribed within a duration.' On every page of the Mourning Diary, continues Compagnon, 'is manifest the desire to stop time, to stand still, to be immobile'. As mourning cannot become the object of narrative, cannot be ordered and rationalized, it 'appears as a series of random occurrences, a succession of moments, intermittencies, flashes of memory, small details that make Barthes think of his mother'. The mourner is an 'erratic Self', 'discontinuous, sporadic, repetitive.' ${ }^{6}$ In Mourning Diary, Barthes wrote: 'I don't want to talk about it, for fear of making literature out of it [...] although as a matter of fact literature originates within these truths.' Some of the pages of the Diary are inscribed with a single stumbling line: 'Nov 11. Horrible day. More and more wretched. Crying.' In a more composed mood, he expresses the hope that writing the episodic book that would become Camera Lucida might be able to 'integrate my suffering with my writing?'

The French subtitle of Camera Lucida, Note sur la photographie, announces its fragmentary, almost haiku-like form. ${ }^{8}$ In the notes for seminars delivered early in 1979, published posthumously as The Preparation of the Novel, Barthes wrote at length about the haiku. It represents a scrap, a sliver of vision - absolutely contingent, subtle, painful, real. It evokes 'what, in a unique instant, once befell the subject: a voice, a sound (contingency defines the perishable, the mortal).' It sparks the 'satori', the Japanese Buddhist term for sudden enlightenment, which Barthes came to associate with the photographic punctum. For him, the haiku's brief notation and the photograph are closely related - they even have a similar appearance as the haiku is often presented as a little block of seventeen syllables centred on an empty page. Both touch on something unspeakable, and so are edged with absence and death - words fail. The key photograph of his mother as a child in a winter garden is not reproduced in Camera Lucida because its non-presence is so eloquent of the trauma, the loss, at the heart of the book. (The discovery of the photograph is reported in the Mourning Diary, 13 June 1978.)

Many precedents for Barthes's adoption of the diary form can be found in early twentieth-century avant-garde art and literature. James Joyce's A Portrait of the Artist as a Young Man (1916), for instance, closes with a series of diary entries. Michael Levenson has argued that this is not to be understood as a reversion to the personal expression of a private self. On the contrary, the diaristic subject is set adrift:

As opposed to the memoir or the autobiography, which typically are written from a fixed standpoint, the diary must continually change its perspective. Its retrospective view is daily rendered obsolete as life outstrips the diary; each entry brings a new retrospect, inviting a restless process of self-correction and self-revision.

He also noted that the intimacy of the diary is sometimes in tension with its periodic, mechanical, repetitive aspects. ${ }^{10}$ 
Another important precedent for the diaristic mode is to be found in surrealist writing. In 'Surrealist Precipitates: Shadows Don't Cast Shadows' (1994), Denis Hollier argued that surrealist autobiographical writing, far from reinstating an authorial ego, was actually a critique of it. According to Hollier, autobiographical writing took the form of a 'search for what, in literary space, would be the equivalent of what a shadow is in pictorial space; an index that makes the work lose all virtuality'. He connects the incorporation of shadows in the visual arts of the 1920s with a contemporary form of diaristic literature. This is exemplified by the anti-novel Nadja (1928), André Breton's first-person account of his encounter with a mysterious young woman who leads him through the streets of Paris. Just as the cast shadow indicates the object, the diaristic 'I' indicates the subject of enunciation, 'opening up language to its immediate performative circumstances. ${ }^{11}$ Motivated by the conviction that the so-called realist novel actually suffered from 'a paucity of reality', Breton included in Nadja named, identifiable characters. The book was actually written retrospectively in the summer of 1927, relying on notes and diary entries taken at the time of their encounters during 1926. Breton's quasi-indexical strategy offered an alternative to the arbitrary, fictitious elaboration characteristic of the realist novel. The many photographs in the book, in combination with the first-person narrative, effected, as Hollier notes, an 'indexation of the tale'. According to his account, diaristic writing, far from being the outpouring of an expressive subject, seems to fall involuntarily, like a shadow. The diary, like a series of snapshots, is an accretion of traces, daily notations. Or, to put it another way, diaristic notation and photography are indexical procedures that disclose 'a world without a self. ${ }^{12}$ Far from implying a fully present authorial subject, then, diaries are circumstantial, accidental and inconclusive, like the sort of books preferred by Breton which are, as he said, 'left ajar, like doors."

Breton's Nadja may seem like a somewhat remote context for thinking about the rise of diaristic visual art after 1970, but one need only consider the work of the French artist Sophie Calle, whose installation/book Suite vénitienne (1979) involved clandestinely following a man around Venice and documenting the activity with snapshots and dated diary entries. Calle was clearly harking back to surrealist precedents, although the conceptual moment in which she was working clearly differentiates her project. This is evident in the 'instructional' character of the work; it is a performative piece, very like Vito Acconci's Following Piece (1969), although she was unaware of his work at the time.${ }^{14}$ Unlike Breton, who was led through the city by a woman with whom he was infatuated, Acconci and Calle surreptitiously followed strangers or near-strangers and so depersonalized their actions. Writing a diary, like following an instruction, involves a certain authorial abnegation that can be mobilized to undermine high modernist notions of the author and artist. For example, the diary adheres to a pre-established calendrical timeline, often laid out in diaristic art in a grid or serial arrangement; it is a minor, sub-literary genre that deals with the everyday in the form of reportage concerning the artist's immediate environment or activity; it is scripto-visual, often combining text with photography, film or video. However, because it is also grounded in the artist's personal experience, it is open to the charge that it reinstates his or her centrality. Yet, as we have seen, the diaristic mode, like photography, actually curtails authorial agency. Both Breton and Calle suspended their author-ity by 'blindly' following someone; at the moment of writing, they had no idea how or where their stories would end.

I want to consider the work of two artists in this context - the Canadian-born, New York-based, Moyra Davey (b. 1958), and London-based Susan Morris (b. 1962). Their work is directly informed by Barthes's and other writers' experiments with a 
diaristic mode of address. Other contemporary artists, such as Tracey Emin or the photographer Nan Goldin, produce powerful autobiographical work, but their raw selfexposure is not 'after Barthes', in the sense I have indicated. The diary form, for Davey and Morris, maintains a certain reserve. However, because their work is informed by Barthes's critique of the presumption of authorial control as well as by the diarist's reluctance to self-censor, it contains some embarrassing revelations of what Davey calls the 'Wet'. ${ }^{15}$ While both artists work in a diaristic mode, their interest in it arises in quite distinct circumstances. These circumstances also distance their work from earlier diarists and theorists upon whose work they draw. Davey's photographic and video projects were initially prompted by the emergence during the 1980s and 1990s of a type of large-scale digital photographic art that was fast replacing the analogue medium. She did not welcome this change, but was also frustrated by the 'white glove' etiquette of traditional fine art photography. For her, writing in diary form, filming or taking photographs of her domestic environment, and presenting the material in book or video form, offered an alternative to the pretensions of both analogue and digital fine art photography. Her work intervenes in the contested field of photography and art as it emerged post-1980. However, her interest in the analogue, in mundane things and everyday life, is motivated by a wider concern with how the proliferation of digital technologies has affected the texture of experience. Her work is also marked by the diagnosis in 2006 of a serious medical condition, accompanied by anxiety, depression and creative blockage. Susan Morris's diaristic practice is also linked to an interest in the relationship between contemporary subjectivity and technology. The work experiments with a mode of writing that mimics photographic capture of the world a mode of writing automatically, indexically, circumventing intention. In this way, she aims to picture the subject's contemporary condition, but also to discover something beyond the culturally constructed ego. Both artists are avid readers of Virginia Woolf, who experimented with an impersonal prose style, struggled with bouts of depression, and kept a diary. Emulating her, both Davey and Morris seek through their work, in texts and images, some form of illumination, epiphany, or what Woolf called 'moments of being'. Above all, they are both writerly artists, meaning that writing is an integral part of their art practice.

\section{Moyra Davey: Photography and Accident}

Davey's 'Notes on Photography \& Accident' (2008) is an essay that consists of brief diary-like entries (some of which are dated) which mainly concern the reading, note-taking and thinking that she was doing in the course of writing. She muses on a collection of quotations extracted from the work of four writers who valued the role of chance in photography: Walter Benjamin, Susan Sontag, Janet Malcolm, and Barthes. She reports occasional galleries visited and lectures attended. There are also intermittent personal entries such as the one-liner dated 28 October: 'Insane mood swings. ${ }^{16}$ The text is interspersed with photos of her domestic working environment including a crowded bookshelf, a pin board, and a few overhead views of a papercluttered glass-top table. The project was motivated by Davey's creative blockage and her search for a way of using photography differently:

I may as well admit it. I'm blocked. I take pictures of the same dusty surfaces, the cherry wood bedside table with its thin coating of linen dust, a colour I know doesn't reproduce well. It will have the same plummy magenta look that I always find a bit sickening. A week later I pick up the film: no transformation. (84) 
I Moyra Davey, Long Life, Cool White, 1999. C-print, $50.8 \times 6 \mathrm{I} \mathrm{cm}$. (C) Moyra

Davey. Photo: Courtesy of greengrassi, London and Galerie Buchholz, Cologne.
By reading and writing, by entering one art through another, she hoped to revitalize her photography and herself.

In retrospect, we can read the essay as documenting a crucial period of transition after which Davey's photography would form part of an expanded practice combining writing, performance and filmmaking. Judging by the photos included in the book, it also marks a moment when she makes her work co-extensive with her daily life; the site of the work is her New York apartment, but correspondingly its interior is partially de-domesticated (plate 1). Yet Davey's malaise, her creative blockage, ran deeper. She was also seeking self-transformation, some revelation or illumination. These three concerns - exploring the contingent, accidental nature of photography, developing an expanded photographic practice, and seeking moments of being - are all broached in 'Notes on Photography \& Accident'.

Davey's attraction to accident is related to her interest in psychoanalysis and surrealism. In The Psychopathology of Everyday Life (1901), Sigmund Freud explained the significance of accident. He argued that common everyday accidents such as forgetting, slips of the tongue or pen, losing things, and bungled actions are ways of allowing unconscious thoughts and desires to attain some form of compromised expression. The analyst attends to 'seemingly unintentional performances [...] normally brushed

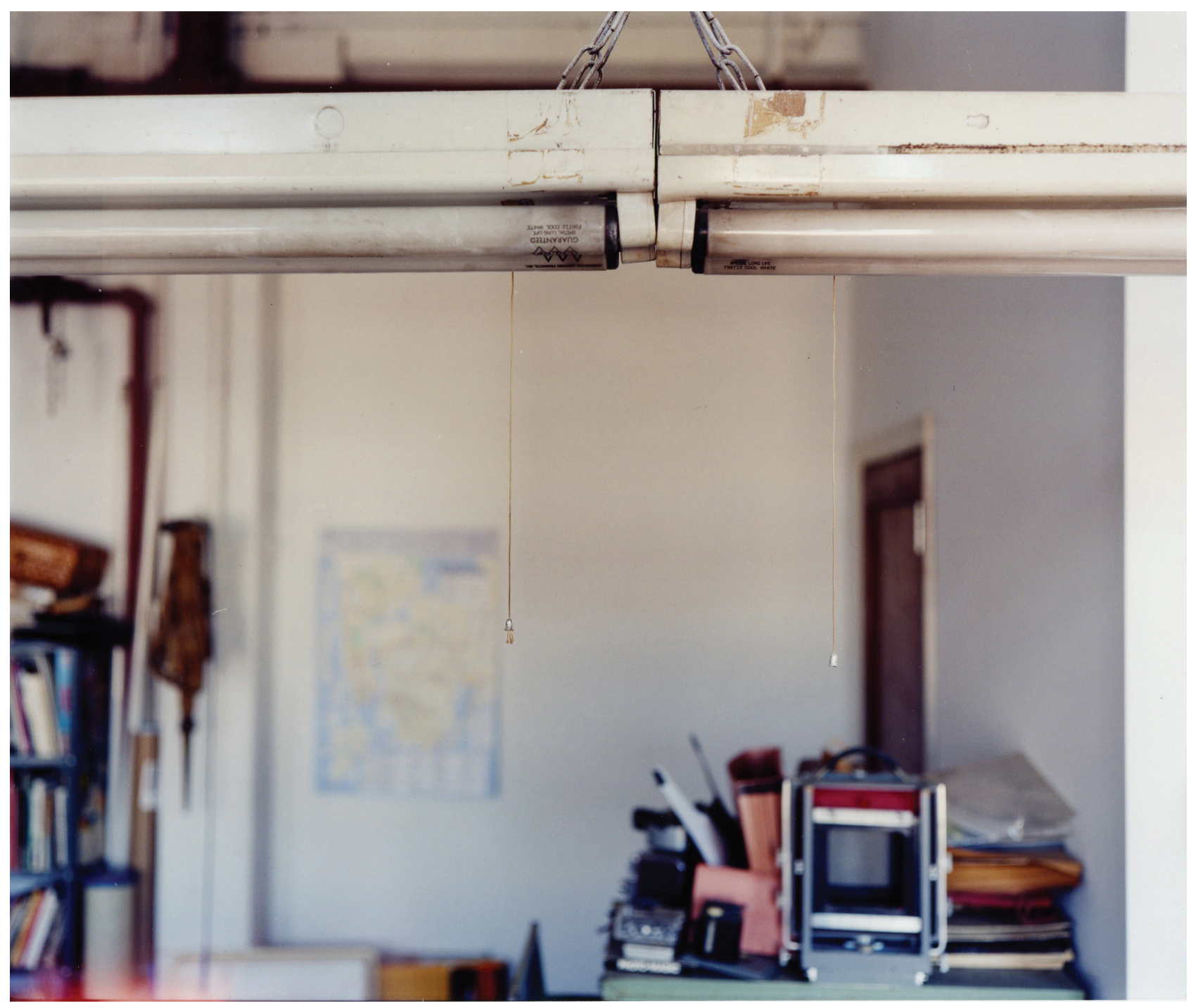


off as meaningless accidents. ${ }^{17}$ In Mad Love (1937), Breton brought Freud's theory of the accident to bear on his ideas of the chance encounter and the trouvaille or lucky find spotted amidst the detritus of the flea market. Reflecting on his found objects, Breton declared: 'it is really as if I had been lost and they had come to give me news about myself. ${ }^{18}$ Davey's attitude to both photography and reading is well described as an openness to the chance encounter's accidental illumination.

Davey's exploration of photography and accident was initially undertaken in the context of photographic art practice in the 1980s. For her, that context included a reductive reading of Martha Rosler's well-known critique of the intrusive and exploitative aspects of documentary photography. ${ }^{19}$ This critique encouraged a practice of deliberate, obvious staging (90). At the same time, advances in the quality of digital capture and printing technologies created a situation in which the art market's demand for the big and flashy could easily be satisfied by a new type of photographic art. This dominant trend in art photography (large, theatrically staged and/or digitally manipulated), well exemplified by the work of Jeff Wall or Andreas Gursky, prompted Davey to explore the possibilities of an altogether different photographic ideal.

The problem, to state it baldly, is one of stilt coupled with bloat. Absent from these oversized tableaux is the inherently surrealist, contingent, 'found' quality of the vernacular photograph, the quality my quartet of writers so eloquently identifies and holds so dear. My goal is to reclaim this critical history of ideas in relation to contemporary photographs, and to understand how the notion of accident might still be relevant. (81)

Further on, she observes that 'for some artists it makes no sense to produce a photograph that is not self-acknowledging "as a construction”, but I still stubbornly cling to those artists, like Francesca Woodman, who did it without dusting the hairs from the gate' (111). Accident, she declared elsewhere, is 'the thing that has gone missing in contemporary art. ${ }^{20}$ Davey's relatively small-scale photos, which show mostly modest still life subjects and domestic interiors, suggest, as Helen Molesworth has noted, 'a deeply submerged feminist agenda.'.

During the early twentieth century, art as a model of consummate control was challenged by avant-garde practices that encouraged the intrusion of chance and welcomed the contingencies of everyday life. Photography once had a certain privilege in this respect, partly because of the gap between exposing and developing film. As Davey notes, before digital pre-visualization, 'the delay, the waiting and the anticipation, were all part of a process that embraced accident and contingency' (109). Her continued use of analogue film in the face of its near obsolescence is one of the means that she employs to retain or revive this vital aspect of photography. She points out that both Sontag and Malcolm view accident as 'the vitality of the snapshot, to which they oppose the turgidity and pretentiousness of art' (106). Tracking down other advocates of chance procedures, she finds on her bookshelf John Cage's Notations (1969), and opens it to discover that someone has written in the margin:

'I mix chance and choice somewhat scandalously.' I copy this phrase into a notebook, a perfect encapsulation of my own desire for contingency within a structure. I decide to allow chance elements, the flânerie, as it were, of daily life, to find their way into this essay. (86) 


\section{Writing}

Although Davey set out to write about photography and accident, she is equally preoccupied with the theme of photography and writing. As she later acknowledged: 'one of the ways I'd kept photography alive for myself was through writing. ${ }^{22}$ The writing that she values and emulates is punctuated by slippages of language like those she finds in Malcolm's prose: 'Malcolm's writing breaks ever so subtly with the decorum of journalistic worldliness to hint at something personal, painful even, about Malcolm herself.' Some of her remarks, writes Davey, have

the quality of a Freudian slip, that crop up in the essays and give the reader pause. [...] It is tempting to call these punctum moments, small ruptures in the stadium [...] of Malcolm's flawless, expository prose. For Barthes, the punctum could not be willed, and while Malcolm's interjections are clearly not accidents, they have a strong unconscious quality. (82)

As a reader, Davey acts like an analyst listening for revelatory 'punctum moments'. She attends to tone, mood and stylistic quirks as much as to the views expressed.

'Notes on Photography \& Accident' is an experiment in combining text and photography. 'I want to make some photographs, but I want them to take seed in words', Davey says (81). The two media, after all, have much in common. As she observes, photographs have been embedded in books since the invention of the process (92). She regards her own note-taking practice as akin to photography, for she goes 'into the world of other people's writing and takes snapshots' (108). She also photographs or videos stacks of books, including a teetering pile of her own diaries, pages of open books and newspapers with underlined passages, and the faded fore edges of books rather than their spines (plate 2). Her approach to integrating writing in her work differs from those conceptual practices that flourished during the 1970s and 1980s when 'scripto-visual' strategies were aimed at discouraging credulous consumption of photography and film. However, one work from the 1970s, Mary Kelly's installation and book Post-Partum Document (1973-79), has a marked diaristic component. Kelly channelled the trauma of her own post-partum losses into an ambitious six-year project which challenged the prevailing impersonality of conceptual art by including in it a 'subjective moment'. ${ }^{23}$ A conceptual artist, with commitments to feminism and psychoanalysis, Kelly documented events as they unfolded in her own life. In one of Davey's videos, she is seen taking Kelly's book from her shelf and blowing dust from it, seeming to breathe new life into it.

A more proximate context within which to situate Davey's work is the current literary trend of autofiction, including the quasi-autobiographical books by writers such as Chris Kraus, Maggie Nelson and Claudia Rankine. ${ }^{24}$ More recently, these authors have been discussed in terms of what is called 'autotheory', a new literary genre that combines personal experience and poststructuralist theoretical reflection. Ralph Clare defines the genre in terms that chime with the work of both Davey and Morris, observing that it is concerned with 'the exposure of a vulnerable self that recognizes its contingency and social/linguistic constructedness while nevertheless insisting upon the "reality" and value of lived experience'. In autotheory, the personal is political and theoretical. A key role in the development of this genre is played by feminists, those identifying as LGBQT+, and people of colour, all of whom bring their lived experience to bear on theory's abstractions. These writers convey 'the lived experience of a nevertheless impersonal I', and unmoor theory from the drag of its academic language and conventions. ${ }^{25}$ 


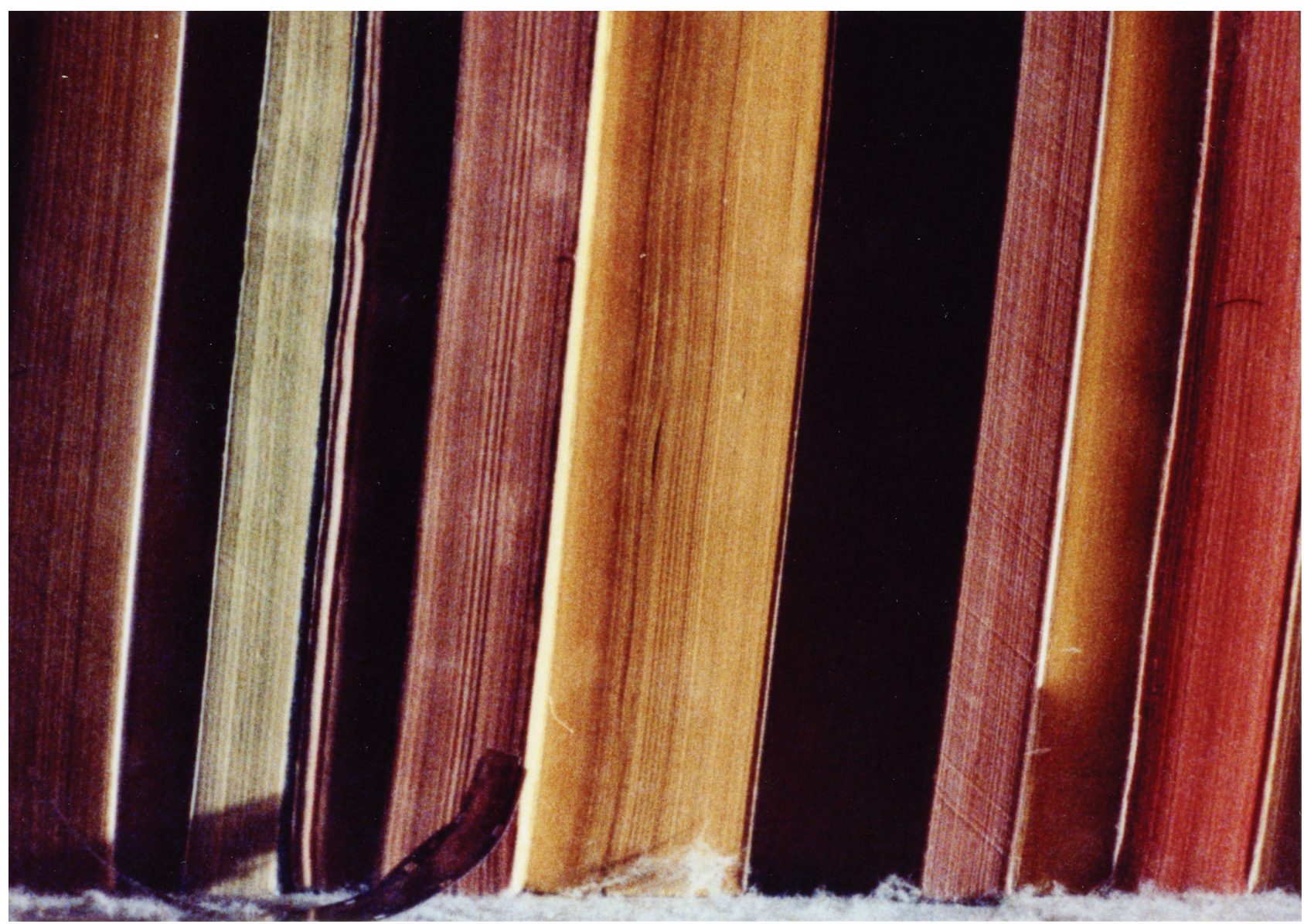

2 Moyra Davey, Film I, 1999. C-print, $50.8 \times 61 \mathrm{~cm}$. () Moyra Davey. Photo: Courtesy of greengrassi, London and Galerie Buchholz, Cologne.
Toward the end of 'Notes on Photography \& Accident', the puzzling references to doses of interferon, insane mood swings and visits to the hospital are explained: Davey had recently been diagnosed with multiple sclerosis. The essay does not dwell on this devastating fact. Rather, it is driven by a desire to find a means of working that would produce something akin to Woolf's moments of being, that is, exceptional moments that would stand out against a background of routine mundane activities. Woolf is an insistent presence in 'Notes on Photography \& Accident'. As Davey said: 'The ampersand between "Photography \& Accident" is to remind me of Virginia Woolf, who made regular use of the symbol, writing for instance of her habit of "reading with pen \& notebook"' (84). Woolf did not write about photography and accident, but in a 1926 essay she did comment on cinematic accident. Davey draws attention to the way that Woolf located cinema's potential, not in its parasitic relationship to the novel, but in an 'accidental scene [taking place in the background] - the gardener mowing the lawn' (110-111). ${ }^{26}$

Davey makes implicit comparisons between the unpretentious use of the camera and certain 'low', literary genres such as diaries and letters. With her series of 'mailers', she grafted photography onto these sub-literary forms. The series was inspired by the practice of her Toronto gallery, Goodwater, of sending publicity mailshots in the form of poster-sized photographic prints, folded so as to expose the image. For her mailout, Davey sent screenshots of her video Fifty Minutes (2006). This casual way of treating the photograph, which involved folding, taping, stamping, addressing and sending photographic prints through the post, where they acquired more marks, appealed to Davey. When unfolded, the posters are marked by the grid of folds and constellated by 
3 Moyra Davey, The Coffee Shop, The Library, 20II. 25 C-prints, tape, postage, ink, each $30.5 \times 44.5 \mathrm{~cm}$. New York: MoMA. () Moyra Davey. Photo: MoMA/Scala, Florence. brightly coloured bits of adhesive tape. The mailers were, for her, a way of 'turning the photograph back into an object, making it a more casual thing, making it something you can handle, giving it this epistolary thrust. ${ }^{27}$ In one series of mailers, sent from Paris to her New York gallery, she seemed to want to accentuate their papery character by taking photographs of bits of paper, mainly notes and tickets left by visitors on the graves of famous people, such as Jean-Paul Sartre, Simone de Beauvoir and Charles Baudelaire. Another series, The Coffee Shop, The Library (2011), consists of a grid of twentyfive shots taken inside the MoMA library and archive, together with overhead shots of Paris café table-tops (plate 3). The orderly repetition of the grid arrangement suggests habitual daily activity. In The Preparation of the Novel, Barthes alluded to his 'daily practice of notation', often seated in a café. Davey cites these seminars in the bibliography of 'Notes on Photography \& Accident'. ${ }^{28}$

\section{Fifty Minutes}

Fifty Minutes (2006) is Davey's first experiment with using video as a medium to combine photography and writing. ${ }^{29}$ It takes the form of the artist delivering a monologue, either speaking to camera from a memorized text, or roaming around her apartment reading aloud, or displaying pages of books, or leafing through her own photo archive. ${ }^{30}$ The video weaves together a number of themes, but, as indicated by the title's allusion to the analytic hour, one important strand concerns her long and rather unhappy experience of psychoanalysis. She mentions 'unspeakable' things that she felt obliged to confess in accordance with Freud's 'Fundamental Rule' of analysis, but she does not divulge them in the video. Rather, she provides circumstantial
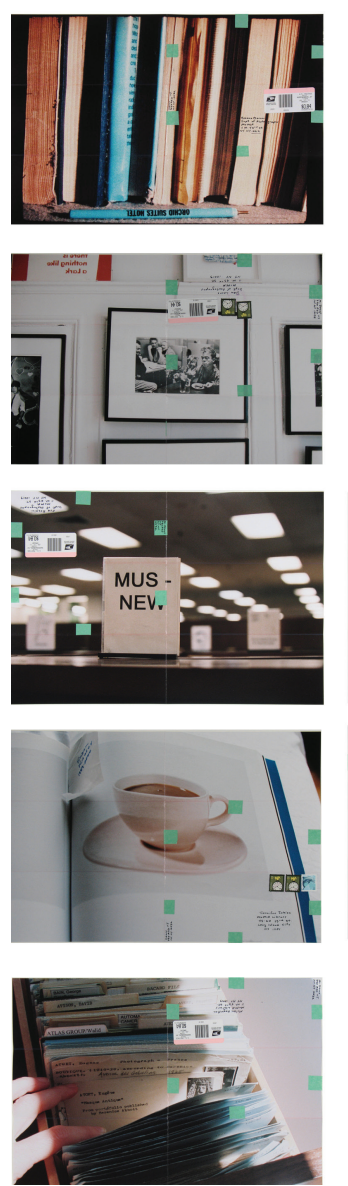
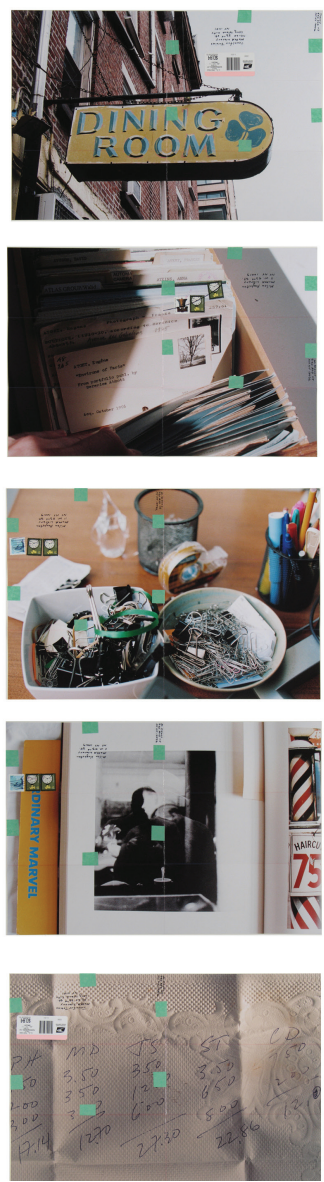
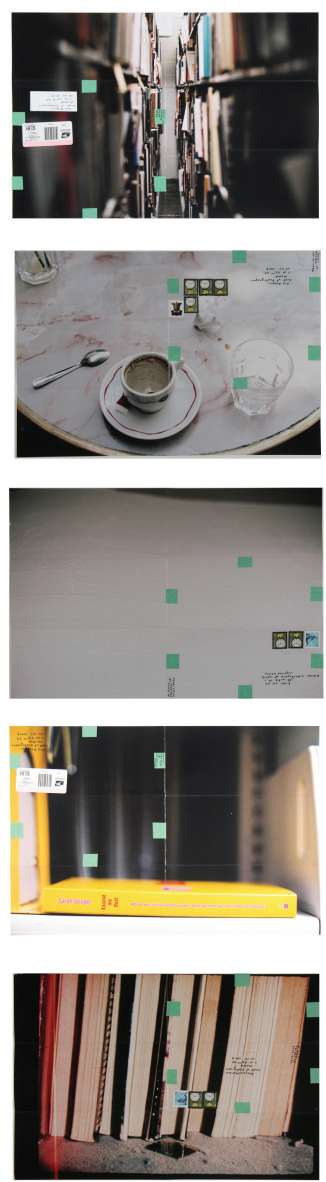
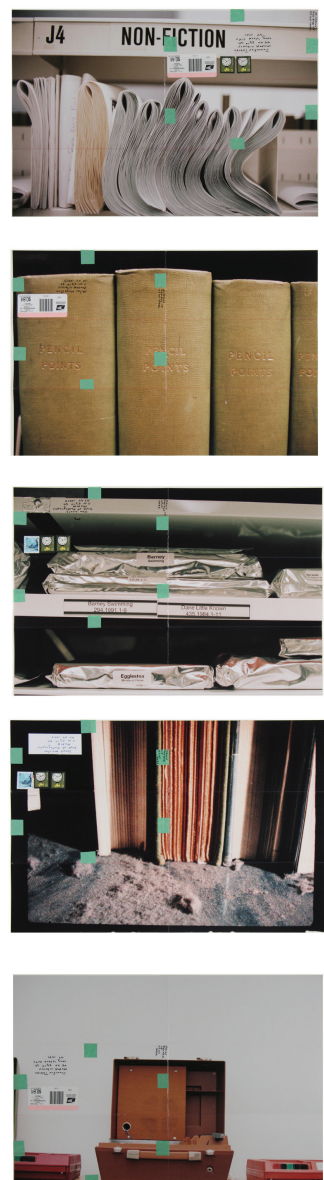
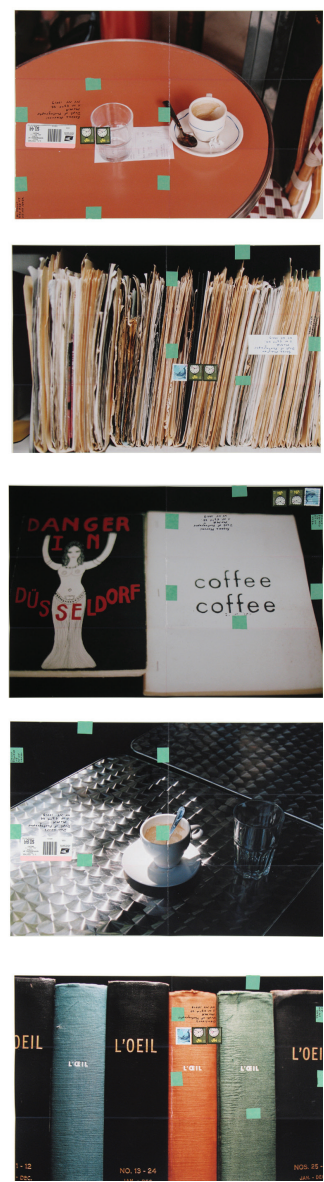
information about her experience such as long subway journeys, the naff décor of the room, the analyst's appearance and his formal, ritualized behaviour. Basically, she was irked because he seemed to be 'incapable of spontaneity or originality'. He went 'by the book'. The video, made after she unceremoniously quit her analysis, is an attempt to find an alternative means of overcoming her fear, her sense of things spinning out of control. ${ }^{31}$

Davey's reflections on her experience of psychoanalysis are interspersed with a commentary on 'Reading in an Age of Uncertainty' (2001), an article by Vivian Gornick about the work of three women writers, Natalia Ginzberg, Anna Akhmatova, and Elizabeth Bowen. As Gornick observes, all three women wrote books marked by the catastrophic historical events that they had endured. And yet their prose is unsentimental:

A remarkable stillness suffuses the prose in each; a stillness beyond pain, fear or agitation. It is as though, in each case, the writer feels herself standing at the end of history - eyes dry, sentences cold and pure - staring hard, without longing or fantasy or regret, into the is-ness of what is. ${ }^{32}$

What these writers lack is nostalgia. Following this paragraph, Gornick's article switches to the present tense of her writing in New York four months after witnessing the fall of the World Trade Center. In this indirect way, Davey introduces one of the principal themes of Fifty Minutes. Her diaristic video was meant to convey, without sentimentality or nostalgia, something of the anxiety and trauma that she and others had experienced on 11 September 2001. Davey remarks that, during her psychoanalysis where 'muck spewed forth', she got some solace from the great ballast or counterweight that was Manhattan, but now its former reassuring solidity and continuity could no longer be assumed. She concludes that, post 9/11, a mythic form of nostalgia lay in a heap of rubble. ${ }^{33}$ Yet, aware that a sense of historical continuity and hope for the future go hand in hand, Davey refers to a book by Svetlana Boym called The Future of Nostalgia (2001) that introduces the concept of 'reflective nostalgia' which, unlike mythic or 'restorative nostalgia', is a 'perpetually deferred homecoming'. As an example of 'reflective nostalgia', Davey offers a memory of her own (she called it a 'screen memory' in email correspondence):

As I write and think about this abstraction, nostalgia, a particular landscape always presents itself. It involves a summer day, a park in Montreal, '60s-era architecture, my mother, and a scene from an Antonioni film. But I can't say more than that. To do so would be to kill off the memory and all the generative power it holds in my imagination. ${ }^{34}$

She believes that the generative or redemptive power of this moment of being depends, to some extent, on its being unanalysed, unrepresentable, incommunicable.

These reflections cast light on Davey's ubiquitous dust imagery. In one scene of the video, she blows dust off the tops of books; in another, a corner of her library swarms with agitated motes of dust, as in a snow globe. ${ }^{35}$ Dust is a memento mori and one that is especially appropriate in the case of 9/11. In an interview, she noted: 'My approach to photography is essentially Barthesian, in that it is about mortality. ${ }^{36}$ Yet the dust imagery also seems to be related to her attraction to the patina of things, like old books, which she lovingly photographs, and her allegiance to the slower time of analogue photography - the gradual accumulation of dust being an index of duration, like sand 
filling an hourglass. Dust also represents the antithesis of an immaculate, digitally 'enhanced' world. As David Campany has argued, it is the 'other' of modernity - 'it has to do with what progress must leave out or suppress. Waste, excess, the irrational, violence, androgyny, boredom, the unconscious [...]. ${ }^{37}$ In a feminist context, sweeping dust has long been part of the Sisyphean torture of housework. Yet Woolf compared her diary writing to sweeping and claimed that writing quickly in her diary has the advantage that 'it sweeps up accidentally several stray matters which I should exclude if I hesitated, but which are diamonds in the dust heap' (Monday 20 January 1919). She thought that 'this loose, drifting material of life' might be capable of transformation: 'there looms ahead of me the shadow of some kind of form which a diary might attain to' (Easter Sunday, 20 April 1919). Woolf transforms this residue of things into something generative, the very 'material of life. ${ }^{38}$ Dust, it seems, can breed.

Another recurrent motif in Davey's work is her refrigerator. Fifty Minutes is bookended by mentions of her neurotic relation to the fridge, the contents of which must be consumed before they spoil. Although the fridge-neurosis is clearly a microcosm of the wider cultural pathology of over-consumption and guilty purging, Davey explains that her anxious controlling behaviour is a displaced anorexia, a witness to her deluded idea that by 'fixating on the process of consumption and replenishment I can control my destiny. ${ }^{39}$ Fifty Minutes, she later acknowledged, has 'a strong diaristic element' and was in some way symptomatic of a need 'to contain and remember. ${ }^{40}$ Post-2020, viewers of the video are likely to see in Davey's domestic confinement, anxiety and proximity to illness something akin to what we have all suffered during the global pandemic.

\section{Index Cards}

Written intermittently over the course of 2008-09 during Davey's residency in Paris, 'Index Cards' is another diaristic essay. ${ }^{41}$ It addresses more directly the question of how to adapt her working methods to her medical condition. In conversation with the writer Maggie Nelson, she admitted that the piece, written out of pain and fear, was woven of quotations taken from writers she loves as 'a talismanic cocoon to stave off fear. ${ }^{42}$ Like Mourning Diary, it consists of brief diary entries including a few truncated sentences often about the difficulty of writing in the grip of fear and pain. In the catalogue Speaker Receiver, 'Index Cards' is preceded by reproductions of four of Davey's mailers, all of which show views of the ceiling: one shows a lighting fixture with two bare bulbs, and a small constellation of glow-in-the-dark stars. She has produced several works consisting of shots of lighting fixtures, including the mailer Bulbs (plate 4). The reason for this unusual point of view becomes clear in the first entry of 'Index Cards', dated 20 December; it cites Benjamin's 1931 letter from Paris to his friend Gershom Scholem in which Benjamin reported that now he only writes while lying down on a divan where he has a view from his window of a clock tower - 'a luxury it is difficult to do without. ${ }^{43}$ Davey imagines the exiled and anxious Benjamin 'finding stability and reassurance in its presence.' ${ }^{44}$ The letter is the starting point for Davey's essay and associated photographs about writing, illness, and the progress of her photography/video project about cemeteries, My Necropolis (2009). She seeks out writers who "have described supine or convalescent views of clouds, patches of blue sky, blossoms, or the crowd seen with the innocence of a child. The look of the world altered by illness. ${ }^{45}$ Quotations concerning a horizontal bodily orientation relate to Davey's search for a new way of viewing the world or her discovery of how illness has in fact transformed her view of the world. What adjustments need to be made? Is it possible to respond creatively to illness? ${ }^{46}$ 


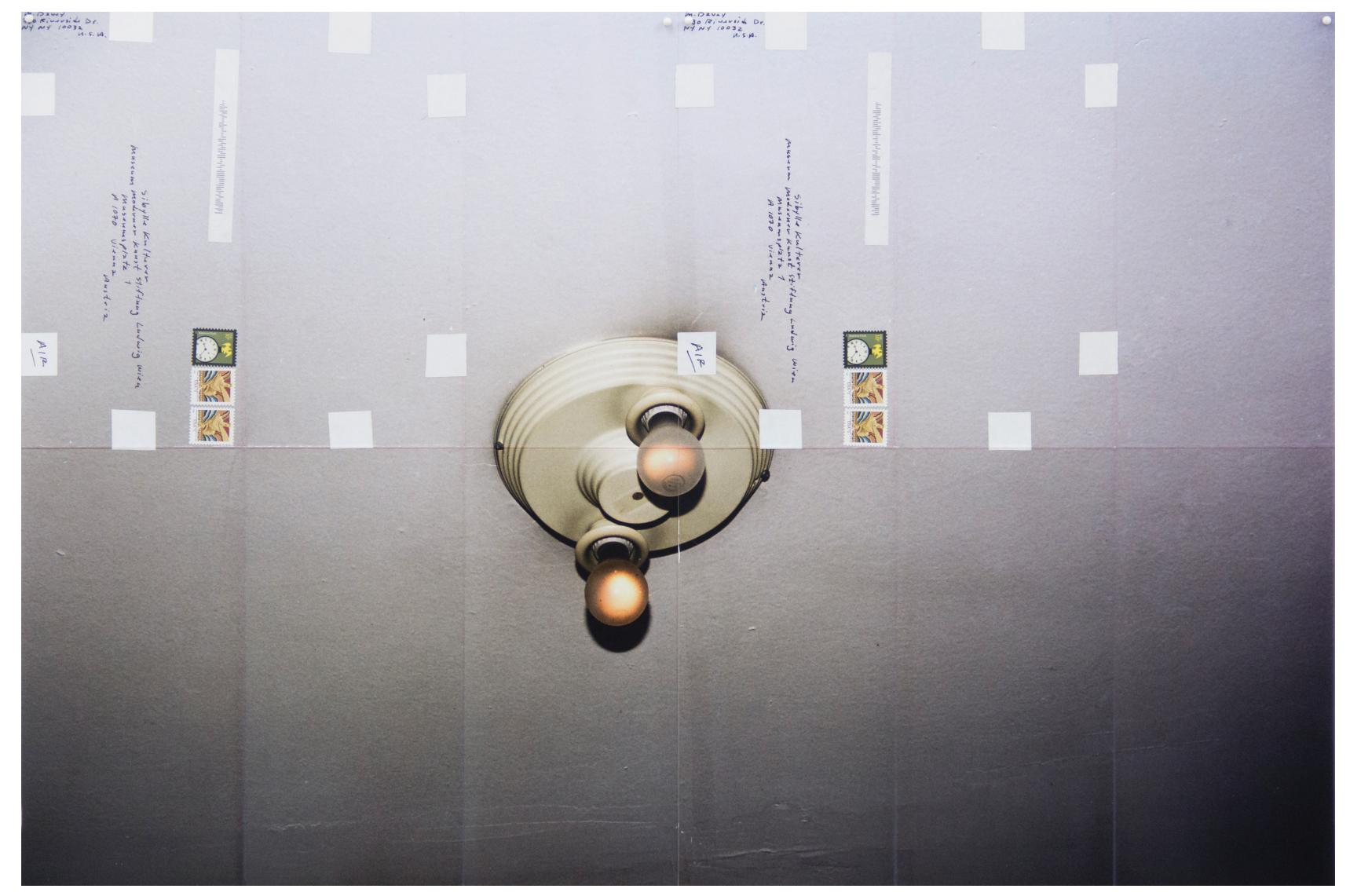

4 Moyra Davey, Bulbs, 2014. 2 C-prints, tape, postage, ink, each $50.8 \times 38.1 \mathrm{~cm}$. $\bigcirc$ Moyra Davey. Photo: Courtesy of greengrassi, London and Galerie Buchholz, Cologne.
Davey's brief diary entries mimic her reading matter: 'I am trying to write in the form of things that I want to read: diaries, fragments, lists.' These modest bits of prose, like notes on index cards, appeal to her: 'I've often thought that diaries and letters are the real modernism: stream of consciousness without the contrivance.' A story should unfold, she believes, without having to impose a structure on the material - for 'aren't confusion and drift truer to how lives get lived?'47 Davey's diaristic prose does drift, but she constantly makes connections and doesn't lose sight of her ultimate aim which is 'to rekindle the desire to make images', to be creative, to be. ${ }^{48}$ In 'Photography \& Accident', Fifty Minutes, and 'Index Cards', Davey's fear, shock and depression are channelled into an absorbing literary and photographic project concerned with accident, illness, trauma and the sources of creativity. Like Barthes after the death of his mother, Davey envisaged a new life that would involve, above all, a new kind of art practice. An entry in 'Index Cards' dated 28 July reads: 'I am working again. I am alive.'

\section{Susan Morris: Tapestries and Diaries}

The diaristic work of art, as elaborated here, differs from the retrospective memoir or autobiography in its quasi-involuntary and open-ended character - hence Davey's appeal to chance or accident, and the loose-knit structure of her essays. Davey and Susan Morris seek to register a shadow or precipitate of the subject inaccessible to deliberate reflection. For Breton, this aim meant adopting a tone 'as impersonal as possible', like that of a neuropsychiatrist. He likened surrealists who practised this rigorous method of writing to 'modest recording instruments', indicating that certain technologies, such as the cardiograph, might serve as models. ${ }^{49}$ Morris shares Breton's strategy of scrupulously recording activities and impressions, but she literally uses a 
'modest recording instrument', that is, a scientific-medical self-monitoring device that tracks levels of activity and rest. Mary Ann Doane has argued that the capacity of recording technologies to capture the contingent, 'the rupture in the fabric of existence', is owing to their indexical nature. ${ }^{50}$ The indexicality of certain mediums is prized by some artists because their operation is partially outside of human control: it 'registers without consciousness of registration', and so allows special access to contingency. For Doane, photography and film are potentially ways of 'fulfilling a Utopian dream of resisting the naturalizing force of institutionalized and regularized time. ${ }^{51}$

Yet if photography, film and other recording technologies are potentially resistant to the rationalization of time, they are also partly responsible for it. In another context, Doane discussed how, around 1900, time became palpable. Modern metropolitan life, it became clear, is only possible given the imposition of a standard time. Railways, particularly, demanded synchronization of schedules and clocks. Soon everyone was obliged to wear a watch - 'a kind of prosthetic device extending the capacity of the body to measure time. ${ }^{52}$ Scientists armed with stopwatches began to measure workers' time and motion to calculate maximum efficiency. In short, time became lived differently owing to new technologies, including those of representation. In 24/7: Late Capitalism and the Ends of Sleep (2013), Jonathan Crary argued that the technological conditions of modern life override 'the periodic textures of human life. ${ }^{53} \mathrm{He}$ further proposed that, since the technologies of the Industrial Revolution have now been supplanted, time is again lived differently: the Information Age runs on a homogenous time of sleeplessness.

While Morris's work demonstrates the thoroughgoing penetration of digital technologies into our daily lives, it also aims to show the body's protest against them. Two closely related strands of her work are considered here. One long-term project involved wearing an Actiwatch for five years (2010-15), long before such devices became common. It continually monitored the pattern and intensity of her bodily movements and converted the data for display as multi-coloured graphs. Morris spent one of those years, 2011, collecting material for an unconventional diary, de Umbris Idæarum [on the Shadow Cast by Our Thoughts]. Here, again, the principles of automaticity and indexicality were at work, for many of the diary's entries consist of data from computer-generated slips of paper, such as receipts, tickets and boarding cards. These scraps index the time and place they were acquired - like a photograph of a clock recording the exact moment of its exposure.

\section{Actigraphs and Tapestries}

Prior to the projects based on Actiwatch data, Morris used commercial year planner posters to register daily 'symptoms' by filling in, or rather cancelling out, certain squares with a black marker pen. The resulting irregular pattern of cross-hatched and blank squares might be compared to dark clouds interfering with the pre-established structure of the grid. The apparently random pattern may refer to days of 'being' or despondent 'non-being', as in the series entitled I am ... (Still), which pays homage to On Kawara's series of telegrams, I am still alive, initiated in 1969. In the case of another series, The Artist's Tears Fall Like Rain (2007), the pattern charts recurrent crying jags. The year planner drawings, which formally allude to Cage's score for Imaginary Landscape No. 5 (1952), are both intimate and impersonal, wet and dry. ${ }^{54}$ Or, as Briony Fer put it, the series veers between 'sheer liquid dissolution' and 'dry detachment' (plate 5). ${ }^{55}$

It was but a short step from this minimal hand-drawn registration of variations over time, to the use of a digital self-monitoring device. The Actiwatch, which looks 
5 Susan Morris, The Artist's Tears Fall Like Rain, 2007.

Graphite on paper, $60 \times 90 \mathrm{~cm}$. Photo: Courtesy of the artist and Bartha Contemporary. like a faceless wristwatch, collects data about its wearer's sleep/wake patterns; in a clinical context, the data are fed into a computer program which produces a colourcoded graph showing varying levels of activity - red for the highest level, black for the lowest. Morris's Actigraph prints (2007-9) are scientific infographic printouts direct from the lab, but they have deeper significance: 'The bright colours are the trace of my activity "in the world", and the dark areas, the shadows, are when I'm "out of it”, sleeping and, quite probably, dreaming.' What emerges from this registration of periods of 'being' and 'fading' is an 'intermittence' of the self - its memory blanks and involuntary recollections, its fluctuating presence and absence. ${ }^{56} \mathrm{It}$ is possible, then, to think of Morris's actigraphs and the tapestries that followed as a form of automatic writing that figures something other than the controlling, conscious self. Alternatively, they might be considered as time-based, involuntary, displaced self-portraits, cast from the body rather than representing it. ${ }^{57}$

Morris had the data recorded by the Actiwatch converted into a computer program capable of producing graphic displays in tapestry form on a high-tech digital Jacquard loom. One rationale for making tapestries is that the original Jacquard loom, invented around 1800, used punch cards to programme patterns and is considered to be the original model for the modern computer. SunDial:NightWatch_Sleep/Wake 2010-2014 (MLS Version) (2015) is a large tapestry that compresses five years of data (plate 6). The horizontal axis displays the record of activity across 1,826 consecutive days, while the vertical axis shows the variations of activity during each day. The level of detail is astounding: one weft thread is allocated to each of the 1,440 minutes of the day. What looks like a night sky down the middle of the tapestry indicates the low levels of activity

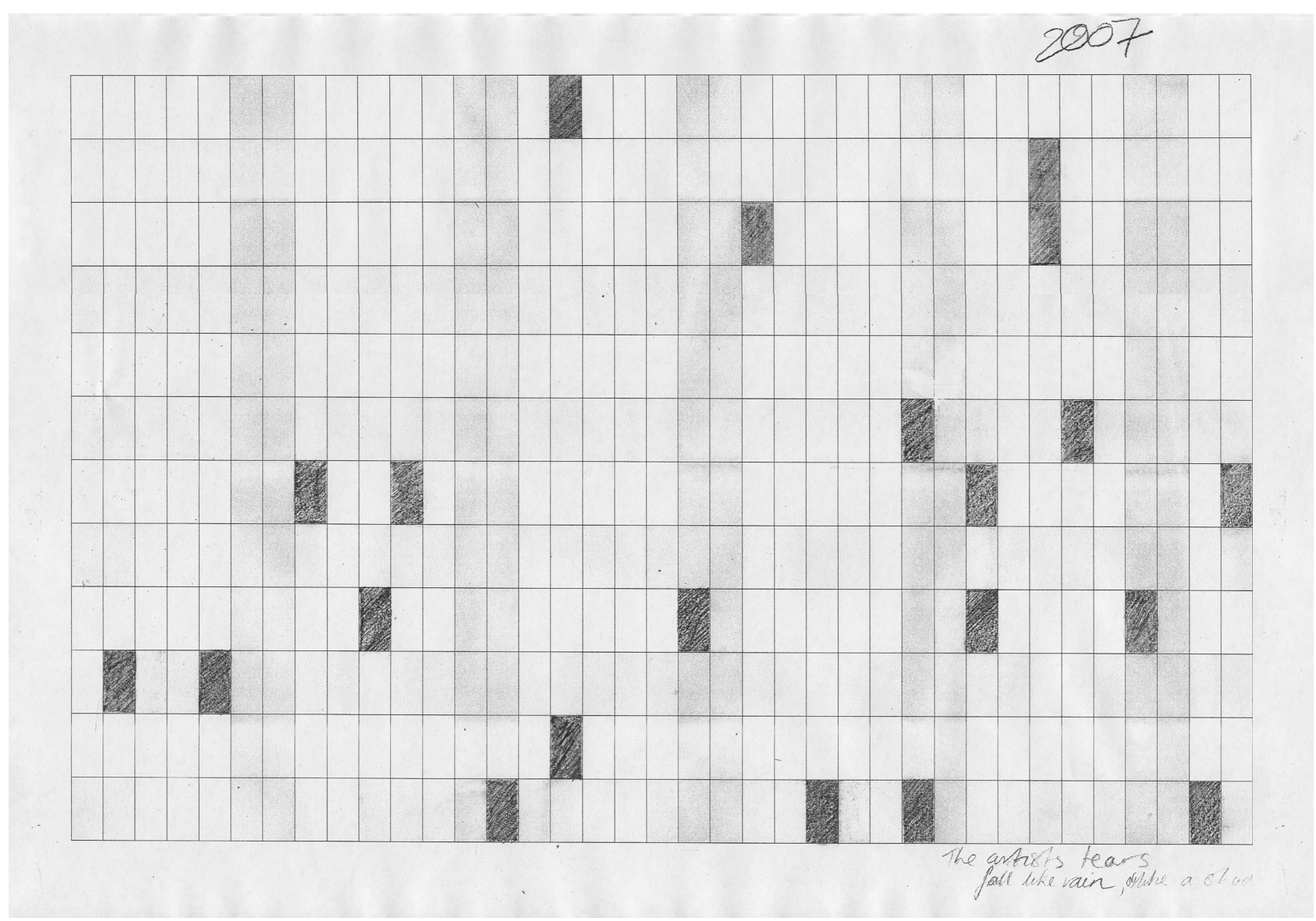




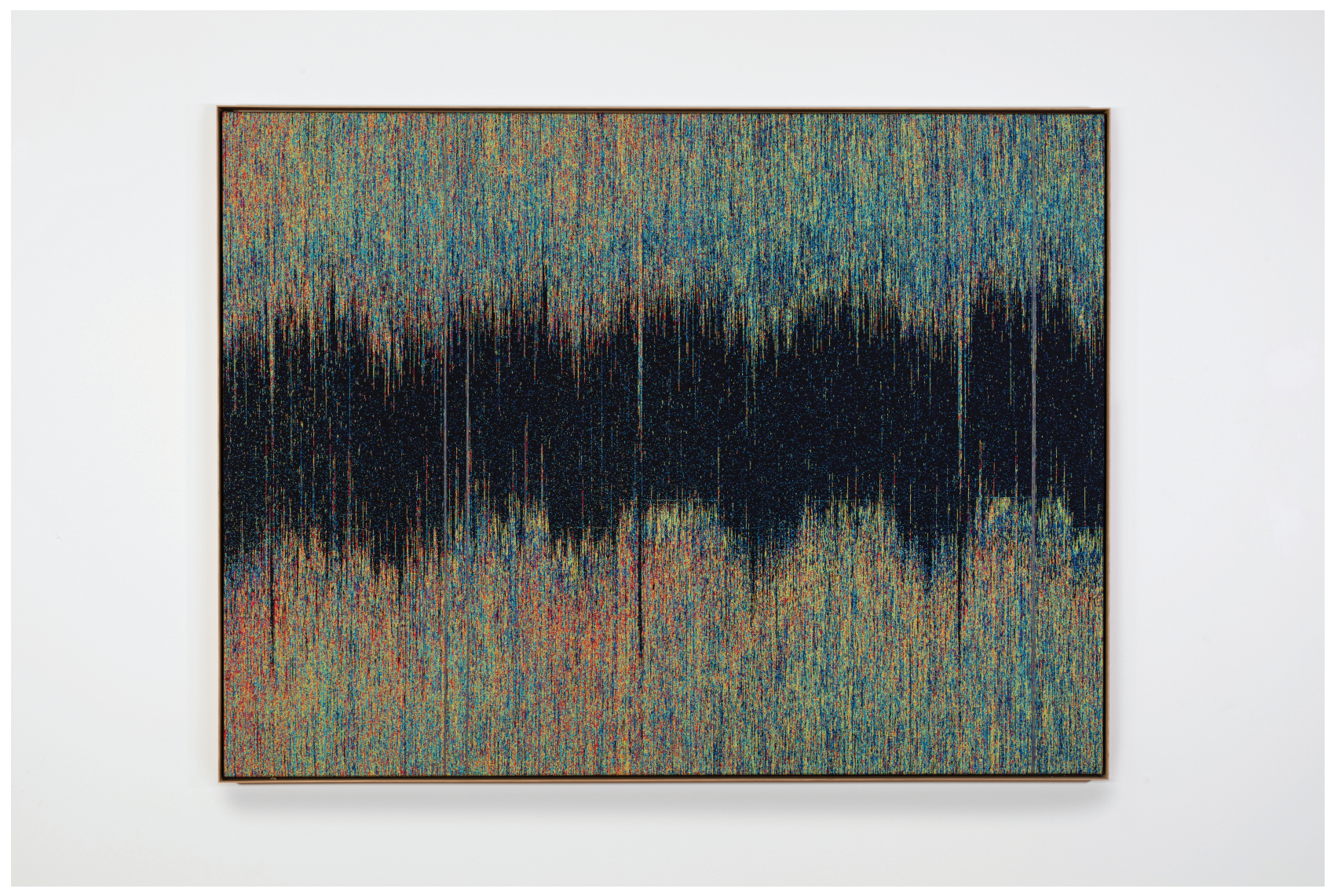

\section{Susan Morris,} SunDial:NightWatch_Sleepl Wake 2010-2014 (MLS Version), 20I5. Jacquard tapestry of silk and cotton yarn, $135 \times 180 \mathrm{~cm}$. Photo: Courtesy of the artist and Bartha Contemporary. when the artist was (fitfully) asleep. A pattern emerges, but there are also notable disruptions to her routine: I learned, for instance, that three jagged time shifts mark trips to New York and that a single, blue, horizontal line tracks an all-night session writing a lecture. Although Morris's tapestries show activity during both day and night, the watch collects the data in the dark, so to speak, digitally registering a behavioural unconscious. As she put it, 'events and phenomena that are untraceable, inexplicable or unconscious are intertwined with lines that mark out the days of the week, the times of the day, of sunrise and sunset..$^{58}$ The indexicality of the process produces a shadow of even the most intimate moments of Morris's daily life, many of which she herself was unaware. In fact, her weaver pointed out a thin, horizontal line indicating a slight movement at exactly the same point every morning which, embarrassingly, turned out to be the trace of her turning off the alarm clock and failing to get up. Clock time and one's bodily rhythms are rarely in sync. By reading the artist's statements and interviews, one can correlate the graphic display to specific events, but it is important to see the tapestries as both dense with coded information and as abstract, shimmering pictures of lived experience in excess of any code.

Morris declared that her aim was 'to find a way of capturing things about my behaviour or mood, my feelings and my actions, that were unpredictable, erratic, accidental or irrational'. ${ }^{99}$ Yet the project also has a more general aim of exploring the constraints imposed and damage inflicted by the rationalization of time, and by the constant surveillance and self-monitoring in contemporary society. The effects of electrical lighting, of organizing ourselves around a 'working day' and, more recently, of a twenty-four-hour lifestyle, often operate at the expense of our natural sleep patterns. Current chronobiological research shows that the ensuing conflict risks 
damage to both mental and physical health. ${ }^{60}$ Indeed, the Actiwatch is itself a prosthetic device used in the service of what scientists in the field call 'sleep hygiene'. Since the device is sensitive to ambient light levels, the tapestries can register the periodicity of the seasons in the northern hemisphere as well as typical work schedules. In correspondence with me, Morris remarked,

I like the way evidence of my individual behavior and habits plus specific events in my private life are set against those determined by shared sociocultural rules and conditions. Both are recorded in the tapestries - the data doesn't differentiate - so we see me living in a city situated in the northern hemisphere during a period of late capitalism, governed by a $24 / 7$ protestant work ethic. ${ }^{61}$

In this respect, the tapestries portray both a specific individual and an anonymous subject going about her daily life like everyone else.

A recent tapestry was aimed specifically at capturing the tension between artificial, socially imposed temporal rhythms and the natural rhythms of the sun's rising and setting and seasonal changes, as well as the body's own rhythms. SunDial:NightWatch_ Activity and Light 2010-2012 (Tilburg Version) (2014) is a mural-size tapestry which shows activity levels and light levels recorded in the artist's immediate environment every day over a period of three years (plate 7). It looks like a painting of a mountainous landscape obscured by a deluge of rain. The 'mountain range' is a record of the changes of light intensity and longevity across the seasons, starting from January 2010, on the left side of the tapestry, followed by the passage of three summers and winters indicated by the bulging and contracting of light areas. The speckled upper band of the tapestry makes visible the level of light pollution in the evenings. Two vertical white lines are the result of lost data - a happy accident the artist compares to hysterical blanking or amnesia. Morris's tapestries register both the effects of technological encroachment and the body's unruly resistance to it. As she wrote:

the Actiwatch's data can show us when we are awake and when we are sleeping but it also reveals moments when we are not necessarily in control, when our bodies break from their typical patterns and reactive processes. Here, as T.S. Elliot put it, 'falls the shadow' ${ }^{62}$

\section{Diaries: On the Shadow Cast by Our Thoughts}

Morris's diary project, de Umbris Idaarum [on the Shadow Cast by Our Thoughts] (2020), comprises twelve volumes corresponding to the months of the year. Each of the small paperbacks is a different colour - a design inspired by the Pelican Freud Library's multi-coloured volumes. ${ }^{63}$ It includes much more detailed information about the artist's daily life than the corresponding tapestry, yet here, too, certain filters are in place. Morris documented her daily life, including encounters with digital technologies, and compiled the information using an app called Evernote. Many of the diary entries are transcripts of receipts that carry information about place and time and, in the case of restaurant receipts, where and what she ate and drank, what she paid and even who served her. ${ }^{64}$

These, along with parking tickets, cashpoint slips and the many other printed records I unconsciously generate as I go about an average day, start to take on a voice of their own, start actually narrating my existence for me. 'I' am reduced 


\section{Susan Morris, Untitled (Activity and Light 2010-2012), 2014. Jacquard tapestry of cotton and linen thread, I55 $\times 589$ cm. Biel: Collection CentrePasquArt, Kunsthaus Centre d'art. Photo: Courtesy of the artist and Bartha Contemporary.}

to the scribble on the dotted line, the scratched-out day on the parking permit or the name on an order of food. ${ }^{65}$

But, as she has noted, this represents only a fraction of the total amount of tracking: 'there are many other tracking devices around me that record what I am doing and how I am behaving that I have no control over and often do not know about, such as those that monitor my credit card usage or my movement through the city, recorded on CCTV or traced back through my mobile phone. ${ }^{166}$ She described her process in an interview:

Throughout 2011, I kept a kind of diary using an app on my phone which allowed me to collect, by photographing, scanning, writing, or recording, anything that caught my attention every day throughout the entire year. Material from external sources, such as newspapers, advertisements, snatches of music or conversation overheard in public spaces, etc., were prioritized over internal commentary or personal opinion. ${ }^{67}$

On the first page of the diary, Morris declares her determination that the diary project be 'unpredictable and spontaneous - irrational even. Above all: it should be FACTUAL'. The citational, found-object, collage-like character of both Davey's and Morris's work owes something to Walter Benjamin's practice of citation and his passion for collecting (plate 8). ${ }^{68}$

The diaries are informed by Barthes's musings on his new practice of writing. In his unconventional autobiography, Roland Barthes by Roland Barthes (1975), under the

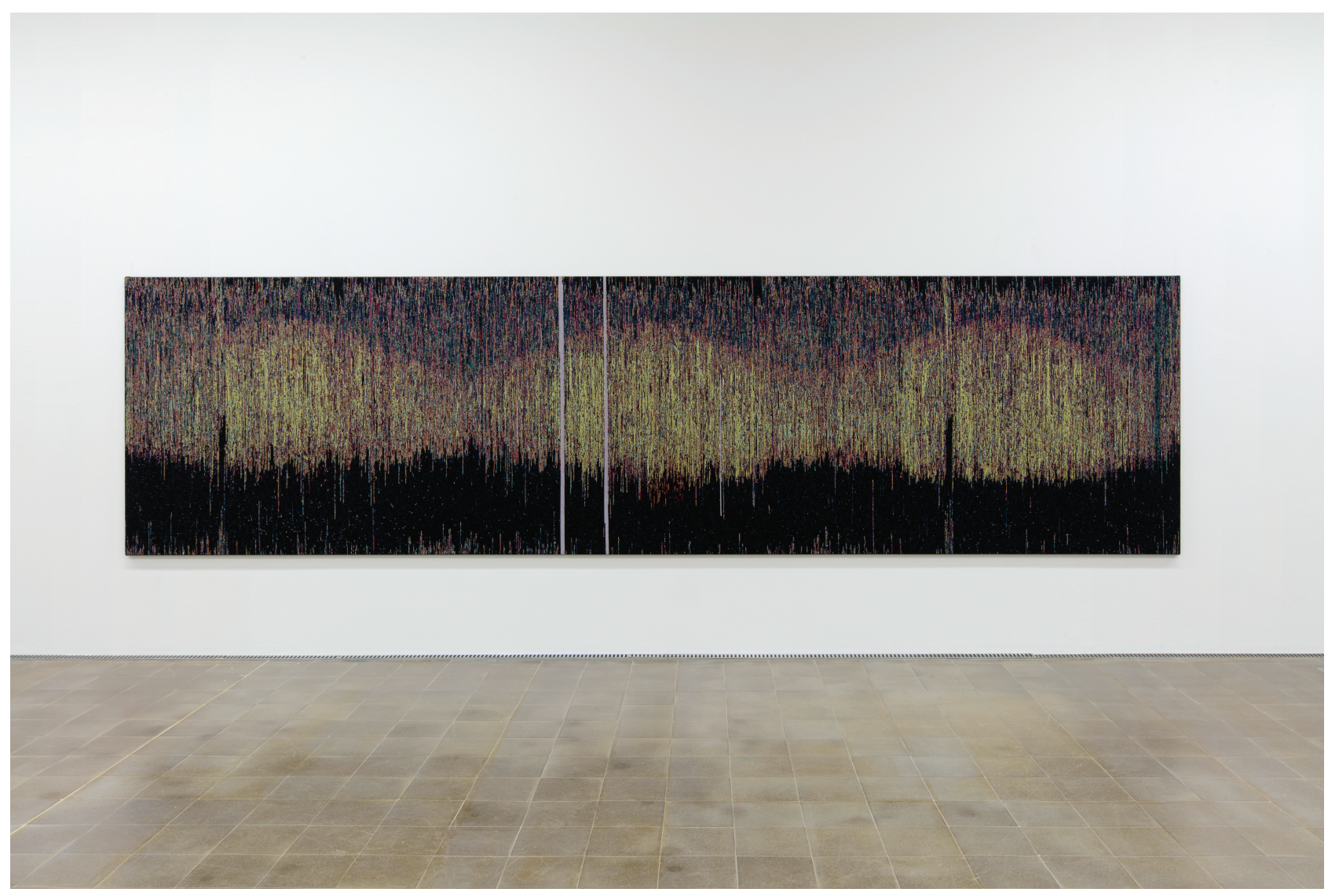




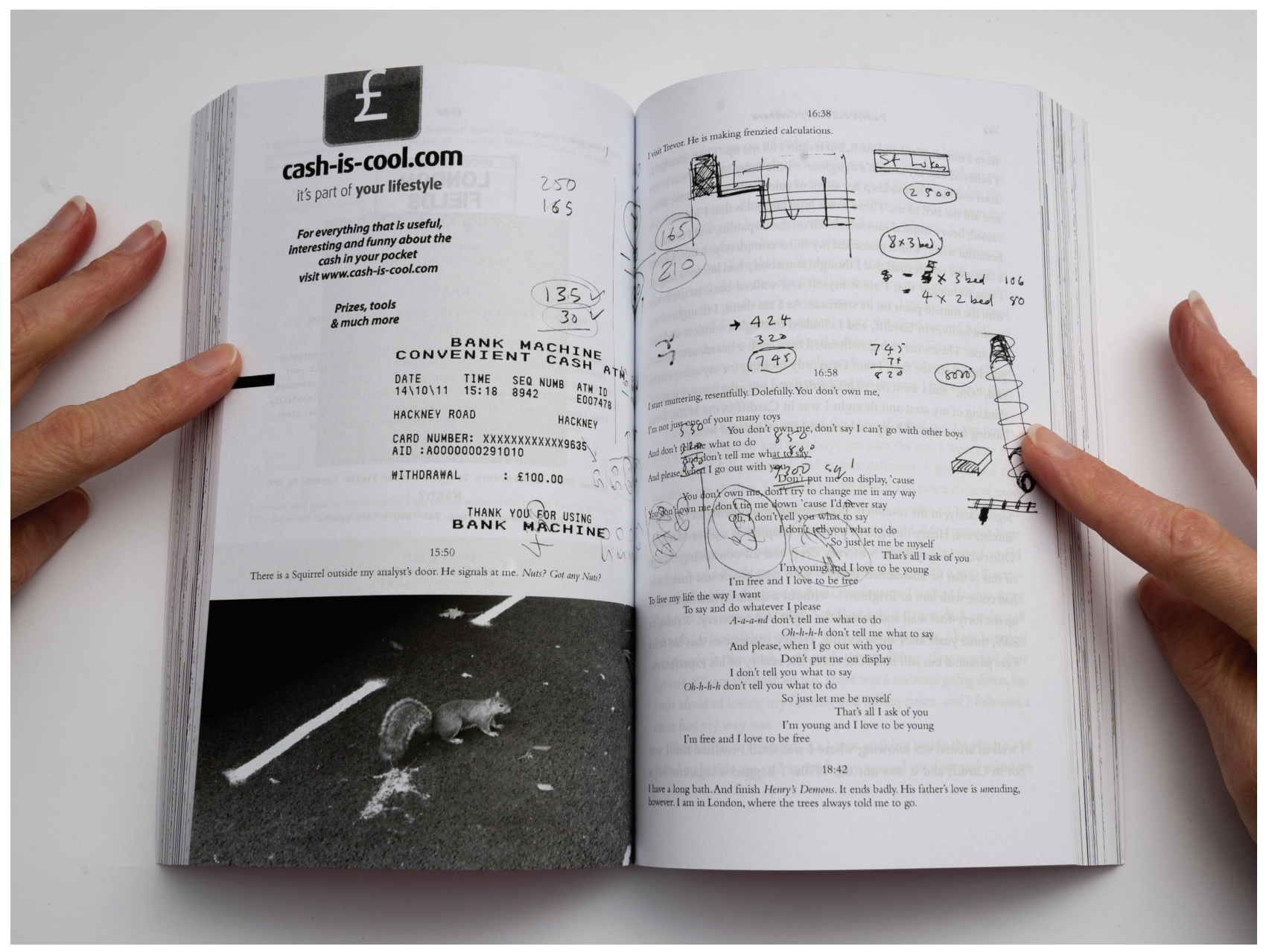

8 Detail of Susan Morris, de Umbris Idæarum [on the Shadow Cast by Our Thoughts], 2020. 12 soft back books, each $21.5 \times 13 \mathrm{~cm}$, with shelf, $25 \times 95 \mathrm{~cm}$. Photo: Photo:

Courtesy of the artist and

Bartha Contemporary. heading 'Projected Books', he wrote: 'Incidents (mini-texts, one-liners, haiku, notations, puns, everything that falls, like a leaf), etc. ${ }^{69}$ In an essay on the writer Pierre Loti, he wrote:

The incident - already much weaker than the accident (but perhaps more disturbing) - is simply what falls gently, like a leaf, on life's carpet; it is that faint, fugitive crease given to the fabric of days; it is what can be just barely noted: a kind of notation degree zero. ${ }^{70}$

Barthes's thinking in these passages recalls Jacques Lacan's remarks on viewing a film of Henri Matisse painting. ${ }^{71}$ Seen in slow motion, the painter's movements suggest that what occurs

as these strokes fall like rain from the painter's brush is not choice, but something else [...]. If a bird were to paint would it not be by letting fall its feathers, a snake by casting off its scales, a tree by letting fall its leaves? ${ }^{72}$

Morris has helpfully glossed this passage:

Lacan compares this movement - the 'rain' from the painter's brush that occurs alongside other, more communicative, gestures - with that which is 
'inhuman', with that which bypasses the culturally imposed symbolic system that organises and orders meaning. In this movement, something 'else' is being traced, marked or mapped out, something that falls, that comes from elsewhere. ${ }^{73}$

Morris's diary seems automatically to register circumambient information, like the Actiwatch.

The self that emerges in the diary is dispersed. As Morris has noted, 'a transient, migratory, "I" passes through many different forms, many different "speakers" e.g. receipts, adverts newspaper articles... Stuff that all goes through or erases the intermittent "Me". ${ }^{74}$ The work dramatizes the fact that the first-person singular ' $\mathrm{I}$ ' is a shifty pronoun, empty until briefly filled by a speaker. As she observed, the

writing appears to be taken, sampled, from the world 'outside' - rather than reflecting the interiority of a constructed self. The words I use seem to simply echo the machinic clatter of the world I am inhabiting. I report this or that using phrases or expressions gleaned from my immediate environment. The things I 'say', respond to and mimic the things I encounter in the world - what I read, the conversations I share, what I hear - like an echo. ${ }^{75}$

This kind of writing relates to Barthes's conception of the text after the death of the author: a text becomes not a linear arrangement of words releasing a single meaning but 'a multi-dimensional space in which a variety of writings, none of them original, blend and clash. The text is a tissue of quotations drawn from the innumerable centres of culture' ${ }^{76}$ This dispersed, fragmentary text remained his ideal to the end, although Barthes's later work, and his idea for a novel, added a diaristic component.

The title of the diary, de Umbris Idæarum [on the Shadow Cast by Our Thoughts], pays homage to W. G. Sebald's The Rings of Saturn (1995) in which a rare book with that title is mentioned in passing. However, the idea that the title conjures of an automatic form of mark-making resurfaces a page later when Sebald's narrator praises seventeenthcentury silk merchants' pattern books containing samples of woven textiles 'of an iridescent, quite indescribable beauty as if they had been produced by Nature itself, like the plumage of birds'. The silk pattern books seemed to him like 'leaves from the only true book, which none of our textual and pictorial works can even begin to rival'.?7 The silk swatches give the impression of having fallen onto the page, having bypassed human intention or fabrication. Morris's textiles, made of iridescent threads, emulate this kind of mark - impersonal, nonhuman, beautiful. Yet, as she remarked, her diaries also aspire to this condition: 'I am really trying to think about the diaries as being like a "true book" - containing only "things that fall". '78 She describes this method of accumulating found phrases and images as 'headless' (plate 9).79

When she was writing her PhD thesis, 'On the Blank: Photography, Writing, Drawing' (2007), Morris was trying to figure out how to write or make a mark from a position of subjective absence. She discovered how to proceed when she learned of the similarity between the operation of photography and a certain kind of novelistic sentence. This is the subject of Ann Banfield's Unspeakable Sentences (1982) ${ }^{80}$ Following Banfield, Morris stresses the link between photography and experimental writing:

In Woolf's novel The Waves, one question is repeatedly formulated: 'how describe the world seen without a self?' It is this question - prompted, as Banfield argues, by the encounter with the photograph - that produced a 
9 Detail of Susan Morris, de Umbris Idæarum [on the Shadow Cast by Our Thoughts], 2020. I 2 soft back books, each $21.5 \times 13 \mathrm{~cm}$, with shelf, $25 \times 95 \mathrm{~cm}$. Photo: Photo: Courtesy of the artist and Bartha Contemporary. new kind of sentence construction; one in which the ' $\mathrm{I}$ ' is absent. This is to suggest that Woolf's written, novelistic, sentence echoes the operation of photography. ${ }^{81}$

In both the photograph and this kind of sentence, there is a description of phenomena from an empty subjective viewpoint - as, for instance, in the italicized sections of The Waves: 'Now the sun had sunk. Sea and sky were indistinguishable'. ${ }^{82}$ This strange 'now-in-the-past' tense is the literary equivalent of Barthes's formulation of the photographic tense, 'thathas-been'. Both circumvent the subject of enunciation and both imply a death-like selferasure. Although the operation of the camera serves as a model for Morris, her work also goes beyond it, exploring the ways in which art and writing have been affected by the proliferation of digital technology.

Digital technology allows me to produce images (such as my tapestries) that trace something enigmatic but related to the body; a body in the grip of a rhythm dictated by its own, unruly, desire. But my thought is that the things that fall into the image - automatically, involuntarily - might also fall across a sentence, might also mark a sentence, like a shadow. ${ }^{83}$

Morris's process has unexpected and revealing consequences. For example, her method of collecting material suggests a condition of digital dependence, while entering receipts of all kinds inevitably foregrounds money and habitual consumption,

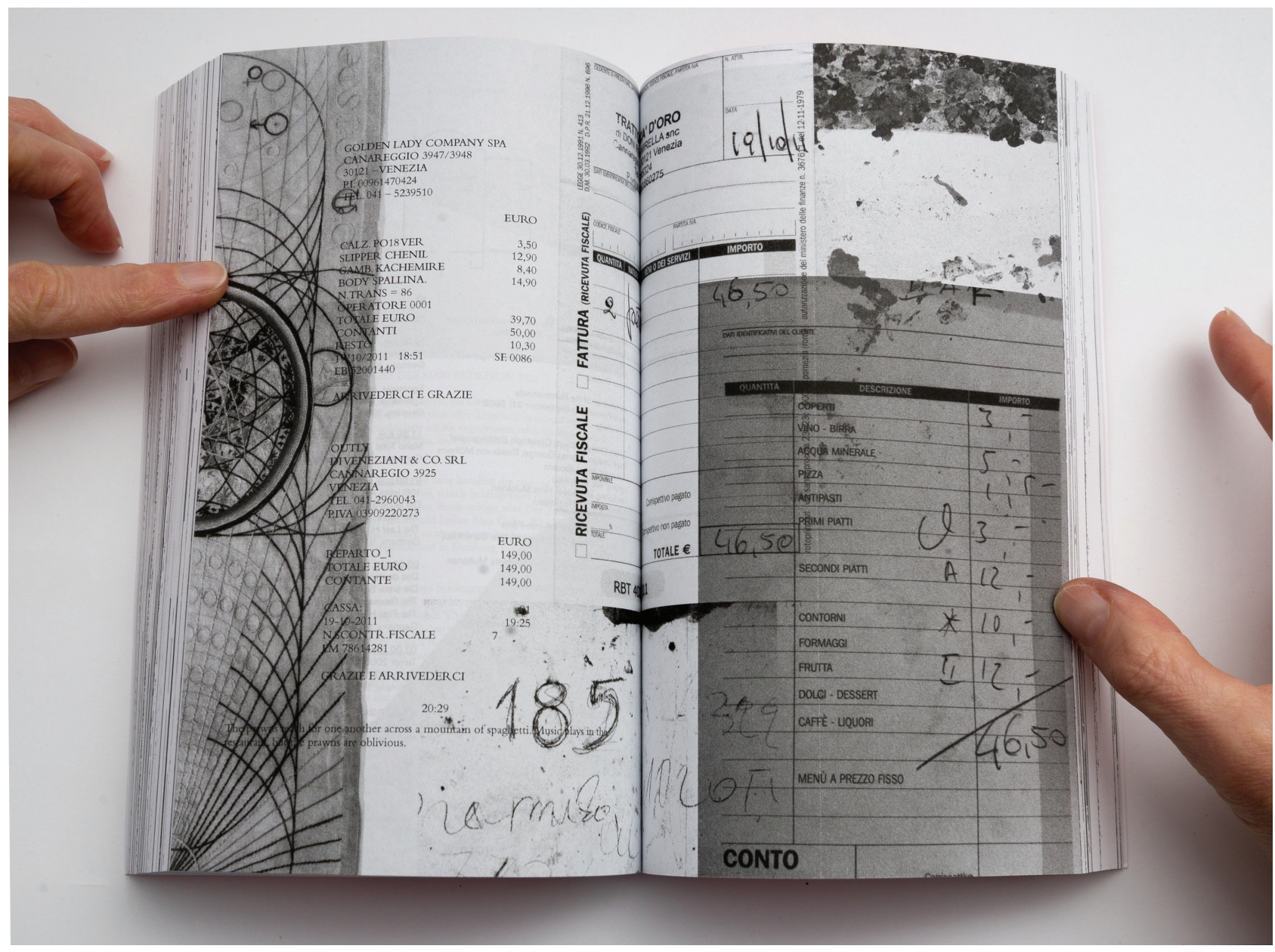


although receipts also carry information relating to seasonal changes and annual holidays, such as frantic last-minute Christmas shopping. Other elements depend more on the restless eye and fluctuating mood of the artist. News stories often concern disasters or their portent. The frontispiece of the March volume hints at strange and unnatural occurrences: it is a download of a newspaper story of 19 March 2011, when, we read, the moon reached its closest point to Earth in two decades. Related to this is the report of a viewing of Lars von Trier's Melancholia (2011), a film about a rogue planet's collision with Earth. The world did not end in March, but the Fukushima tsunami and nuclear power station disaster did occur. Other diary entries are less catastrophic: idly googling something, the computer predicts 'Birds fall from the sky'. Following up on random predictive texts like this is exemplary of Morris's 'headless' method. Googling is treated as an externalized form of free association. Similarly, Morris's eye is drawn to things on the periphery, and these marginal interferences carry disproportionate significance in what seems like a search for meaning in the banality of everyday experience. For instance, the diary reproduces snapshots of the sort of litter encountered in the street such as flyers or notices which, as she put it, is 'treated as a message from a world that "speaks" only to "me". Humour enters at this point. ${ }^{\text {'4 }}$ There is much self-deprecating humour, but the mood is mainly one of foreboding, anxiety or melancholia. In Morris's diaries, as in Davey's, mood swings and psychoanalytic sessions are recurrent themes. In addition, although Morris lacks Davey's penchant for the outmoded, dusty, analogue world, both artists are critical of the computer's escalating impingement on every aspect of life.

Weird weather and climatological changes mirror emotional perturbations; there are photos of looming clouds and the eclipsed blood-red moon, plus news reports of melting glaciers and fierce storms. Yet there are also moments of elation ('The sun is shining!'). Some of the entries were verbally recorded on her phone, automatically transcribed and chronologically ordered using Evernote. Anxieties repeatedly alluded to include ageing, minor ailments, work, pollution and problematic personal relationships. The 'I' complains of depression and nightmares, feelings of hollowness and loneliness. These feelings are echoed in news items about animals and in her own photographs of them - her cat, pre-eminently, but also crazy ducks on the canal, and a little blind dog who sits outside a neighbour's studio on a tartan blanket. The neurotic behaviour of animals is a metaphor for the creaturely condition of human beings, especially those who are confined or exposed to harm. ${ }^{85}$ 'My skin is too thin', she complains, suggesting that the boundary between the 'inside' and the 'outside' is being eroded. Discussing recent art and writing that foregrounds the 'I', Alex Kitnick observed that such work reveals the effects of contemporary conditions: it 'does not mark a return to intentionality so much as it monitors symptoms. ${ }^{86}$ Displaying just such a symptom, the diary contains a downloaded article about a happiness app which promises to track when you are happiest and so improve your understanding of "what makes life worth living'. The irony is that it is just this sort of self-monitoring that contributes to one's unhappiness.

\section{Moments of Being}

In her autobiographical study, 'A Sketch of the Past' (written in 1939 and published posthumously), Virginia Woolf wrote at some length about her 'moments of being', particularly those experienced in early childhood. Weeks would pass, she says, when 'nothing made a dint on me'; but there were also 'exceptional moments', some pleasurable, others violent, that would 'surface unexpectedly' in later life. Certain incidents from childhood made her feel 'exposed to a whole avalanche of meaning that 
had heaped itself up and discharged itself upon me, unprotected, with nothing to ward it off'. Although some of these incidents were clearly traumatic, she judged them to be valuable, for 'the shock-receiving capacity is what makes me a writer'. ${ }^{87}$ A violent shock is also a potential revelation, 'a token of some real thing behind appearances'. 'Reality' in this context is close to what Lacan referred to as the 'Real', that is, something unassimilable and inexpressible. Because Woolf's writing touched on these wordless moments of being, it had for her a quasi-therapeutic value. She recalled, for instance, how writing To the Lighthouse, 'in a great, apparently involuntary, rush', finally laid to rest her obsession with her long dead mother and concluded that 'I suppose that I did for myself what psycho-analysts do for their patients. ${ }^{88}$

To the Lighthouse is one of the works featured in Fifty Minutes when Davey blows dust from her books - a hint perhaps that, for her, too, autofiction might be a creative form of auto-analysis. Davey's work is motivated by her desire to break through what Woolf called 'the nondescript cotton wool' of daily life in a moment of 'ecstasy' or 'rapture'. ${ }^{89}$ Woolf is also a model for Morris. Her tapestries and diaries are presented as 'symptoms' of a modern-day hyper-sensitive woman exposed to the shocks of contemporary digital technologies, who nonetheless uses these same technologies to contain and process the anxiety that they engender. Morris's work figures a fragmented subject caught up in a giant web of mass media overload, electronic tracking devices, omni-surveillance and data collection. Yet she hopes that the work also traces something other, 'a vaporous, bodily unconscious that exists, like a cast shadow, alongside my everyday "self". ${ }^{90}$

The gradual rise of the diaristic mode in art since the 1970s has recently spiked in the form of Coronavirus lockdown diaries produced by both professional artists and gifted amateurs of Instagram..$^{91}$ This rise confirms the link I have indicated between diaries and moments of personal anxiety or public crisis. The diaristic mode might at first sight look like the return of the dead author in a particularly self-absorbed mood. Yet, in fact, the work of both Davey and Morris could well be described as citational: quoting, photographing, filming, recording, sampling, scanning, and downloading are typical procedures. They are diaristic writers as receivers; both artists open the authorial 'I' to others. ${ }^{92}$ However, as we have seen, Davey's assemblage of citations has to do with gathering and incorporating in her work 'found' quotations by writers that she loves, whereas Morris's echo of online chatter and overheard conversations is an experiment in life writing for the digital age. 'After Barthes', the diaristic mode is a means of writing automatically, involuntarily, allowing chance and the unconscious to intervene. It is a mode of writing the self as a site of subjective intermittence and a mode of mark-making that falls like a leaf, or a shadow, or dust.

Notes

Although I have long been preoccupied with the intersection of photography, indexicality and subjectivity, it was Susan Morris who alerted me to the connection between these topics and the diaristic mode. She did much of the original research, both scholarly and artistic, that underpins this essay. I wish to thank her for her generous collaboration.

1 Roland Barthes, 'The Death of the Author', in Image Music Text, trans. Stephen Heath, New York, 1977, 143.

2 Aspen No. 5 +6, 'The Minimalism Issue', 1967. It can be viewed online: https://www.ubu.com/aspen/aspen5and6/.

3 I am thinking particularly of Mary Kelly, On Kawara, Dieter Roth, Ian
Breakwell, Sophie Calle and Felix Gonzalez-Torres. In a wide-ranging article, Alex Kitnick discusses the 'resurgence of the first person' in recent art and literary practices. He mentions several genres including 'autobiography, autofiction, confession, epistle, memoir, personal essay', but he does not consider the specificity of the diary form. The article highlights the work of AIDS activist, Gregg Bordowitz, Frances Stark and Chris Kraus. See Kitnick, 'I, etcetera', October, 166, Fall 2018, 45, 52. See also documentation of the exhibition Day after Day: The Diaristic Impulse, University Art Museum, University at Albany, New York, 5 February- 6 April 2013.

4 Barthes, Mourning Diary: October 26, 1977 -September 15, 1979, ed. Nathalie Léger, trans. Richard Howard, New York, 2010. Some of these discussions took the form of extended reviews. Especially pertinent 
in this context is a review of Barthes's Morning Diary and Preparation of the Novel: Adam Thirlwell 'My Novel, My Novel,' The New Republic, 8 December 2010. https://newrepublic.com/authors/adam-thirlwell. See also two articles by Antoine Compagnon, 'Writing Mourning' and 'Roland Barthes's Novel', referred to below.

5 Barthes, 'Longtemps, je me suis couché de bonne heure', The Rustle of Language, trans. Richard Howard, New York, 1984, 282, 284, 286.

6 Antoine Compagnon, 'Writing Mourning', Textual Practice, 30: 2, 2016, 211, 212. See also, Compagnon, 'Roland Barthes's Novel', October, 112, Spring 2005, 23-34.

7 Barthes, Mourning Diary, 23, 45, 105.

8 Barthes, Camera Lucida: Reflections on Photography, trans. Richard Howard, London, 1982. On Camera Lucida, see my 'What is a Photograph?', in Art History, 17: 3, September 1994, 101-118; reprinted in Margaret Iversen, Beyond Pleasure: Freud, Lacan, Barthes, University Park, Pennsylvania, 2007 and in Photography Degree Zero, ed. Geoffrey Batchen, Cambridge, MA, 57-74. See also Iversen, Photography, Trace, and Trauma, Chicago, 2017.

9 Barthes, The Preparation of the Novel: Lecture Courses and Seminars at the Collège de France (1978-1979 and 1979-1980), trans. Kate Briggs, New York, 52.

10 Michael Levenson, 'Stephen's Diary in Joyce's Portrait - The Shape of Life', ELH, 52: 4, Winter 1985, 1023, 1018. Reprinted in Mark A. Wollaeger, ed., James Joyce's A Portrait of the Artist as a Young Man: A Casebook, Oxford, 2003, 183-205. I can only think of one example of a diaristic approach to art history - T. J. Clark, The Sight of Death: An Experiment in Art Writing, New Haven, 2006. Clark's iterative process of coming to understand two paintings by Poussin is presented in dated diary entries written over the course of 2003.

11 Denis Hollier, 'Surrealist Precipitates: Shadows Don't Cast Shadows', trans. Rosalind Krauss, October, 69, Summer, 1994, 124, 129.

12 The phrase is used by Virginia Woolf in The Waves. I adopted it for the title of an article related to the themes of the present one called, 'The World without a Self: Edward Hopper and Chantal Akerman', Art History, 41: 4, September 2018, 742-761.

13 André Breton, Nadja (1928); trans. Richard Howard, London, 1999, 18.

14 In a similar vein, I argued that the titles of Ed Ruscha's books, such as Twentysix Gasoline Stations (1963), function as instructions for the performance of the piece. Iversen, 'Auto-maticity: Ruscha and Performative Photography', Art History, 32: 5, December 2009, 836-857.

15 The 'Wet', a term frequently used by Davey, refers to abject, shameful events in the past. She defines is as 'certain aspects of the discredited past, things I may never be ready to tell'. Davey, 'Les Goddesses', Index Cards, 110. A nearly text-only version of this essay and several others referred to below are printed in Moyra Davey, Index Cards, edited by Nicolas Linnert, published by Fitzcarraldo Editions in the UK and New Directions in the USA, 2020.

16 Moyra Davey, 'Notes on Photography \& Accident', Long Life Cool White: Photographs and Essays by Moyra Davey, Cambridge, MA and New Haven, 2008, 110. The book accompanied an exhibition of her work at Harvard Art Museum curated by Helen Molesworth. (Subsequent page numbers appear in parentheses in the text.).

17 Sigmund Freud, The Psychopathology of Everyday Life (1901), The Standard Edition of the Complete Psychological Works of Sigmund Freud, ed. James Strachey, vol. VI, London, 1953-74, 239.

18 André Breton, Mad Love, trans. Mary Ann Caws, Lincoln, NE, 1987, 8. Translation of L'Amour fou, Paris, 1937.

19 Martha Rosler, 'In, Around, and Afterthoughts (on Documentary Photography)' (1981), in The Contest of Meaning: Critical Histories of Photography, ed. Richard Bolton, Cambridge, MA, 1989, 303-341.

20 Jess T. Dugan, 'Conversation with Moyra Davey', Big Red and Shiny, 79, 1 April 2008, online journal http://bigredandshiny.org/

21 Helen Molesworth, 'An Introduction to Moyra Davey', Long Life Cool White, 13.

22 Davey, 'Caryatids and Promiscuity,' October, 158, Fall 2016, 25. Reprinted in Moyra Davey, Index Cards, 143-152.

23 Kelly criticized conceptual artists who, she said, 'stopped dramatically short of synthesizing the subjective moment into their enquiry'. Mary Kelly, 'Introduction: Remembering, Repeating, and WorkingThrough', Imaging Desire, Cambridge, 1996, xx.

24 See Chris Kraus's article on Davey's work, 'Description over Plot', in Speaker Receiver (exh. cat.), Kunsthalle Basel and Berlin, 2010, 37-52.

25 Ralph Clare, 'Becoming Autotheory', Arizona Quarterly: A Journal of American Literature, Culture, and Theory, 76: 1, Spring 2020, 86, 94. The issue is devoted to the topic. See also Lauren Fournier, Autotheory as Feminist Practice in Art, Writing, and Criticism, Cambridge, 2021. In The Argonauts (Minneapolis, 2015), Maggie Nelson credits Paul Preciado's influential book, Testo Junkie: Sex, Drugs, and Biopolitics in the Pharmacopornographic Era, (2008), for inventing the genre and the term 'autotheory'.

26 Virginia Woolf, 'The Cinema', in Virginia Woolf: Selected Essays, ed. David Bradshaw, Oxford, 2009, 79.

27 Moya Davey, ICP Photographers Lecture Series, New York, 12 October 2011. https://www.icp.org/browse/archive/media/icp-photographerslecture-series-moyra-davey.

28 Roland Barthes, The Preparation of the Novel, 90. Davey cites the original recordings of the lectures stored on MP3 CDs.

29 Subsequent films made by Davey include My Necropolis (2009), Les Goddesses (2011), Notes on Blue (2015) and Hemlock Forest (2016).

30 In later videos, she plays back a pre-recorded text wearing earphones, repeating it aloud on camera. This technique of performing a written text distances without altogether displacing the author.

31 Moyra Davey, 'Fifty Minutes (Video Transcript)', Long Life Cool White, 128, 133. Davey paid only $\$ 8$ an hour to her trainee analyst (125). Reprinted in Davey, Index Cards, 71-104. Davey's husband, Jason Simon, 'once referred to Fifty Minutes as a replacement for the termination that never happened, the final session'. Email correspondence with the author, 19 September 2018.

32 Vivian Gornick, 'Reading in an Age of Uncertainty', Los Angeles Times, 30 December 2001. http://articles.latimes.com/print/2001/dec/30/ books/bk-gornick30. Cited by Davey, in 'Fifty Minutes', 126.

33 Davey, 'Fifty Minutes', 140-141.

34 Davey, 'Fifty Minutes', 130.

35 For an extended discussion of Davey's dust imagery, see George Baker, 'The Absent Photograph', Speaker Receiver, 179-201. See Baker, 'Lateness and Longing', 50 Moons of Saturn: T2 Torino Triennale, ed. Daniel Birnbaum, Milan, 2008. See also Brian Sholis et al., Moyra Davey, Scotiabank/Steidl, 2019, with essays by Sholis, Ben Lerner, Élisabeth Lebovici and Eric Rosenberg.

36 Davey interviewed by Adam Szymczyk, 'Accidents among the Slow Things', Speaker Receiver, 145.

37 David Campany, A Handful of Dust: From the Cosmic to the Domestic, Berlin, 2016, 14.

38 Virginia Woolf, Selected Diaries, ed. Quinten Bell, London, 2008.

39 Davey, 'Fifty Minutes', 140, 141.

40 Dugan, 'Conversation with Moyra Davey'.

41 The title, 'Index Cards', alludes to Barthes's habit of making notations on small slips of paper that formed the basis of his late discontinuous prose style. When he died, they numbered 12,250. See Denis Hollier, 'Notes (on the Index Card)', October, 112, Spring 2005, 35-44.

42 Davey and Maggie Nelson in Conversation, 'Look and Listen', Artforum, August 2017. https://www.artforum.com/slant/id=70831.

43 In correspondence with me Davey commented: 'I love the connection you make between the ceiling photos in Speaker Receiver and the reclining writers. This never occurred to me! I cannot take credit, it was surely Julia Born, the brilliant designer of that book who made the link' (18 September 2018).

44 Davey 'Index Cards', Speaker Receiver, 16. Reprinted in Moyra Davey, Index Cards, 71-104

45 Davey, 'Index Cards', 18.

46 This is the subject of Woolf's 'On Being Ill' (1926), Woolf, Selected Essays. Woolf remarks on the 'tremendous spiritual change' that illness brings (101). The essay is cited by Davey in 'Index Cards', 17.

47 Davey 'Index Cards', 30, 16, 12.

48 Davey, 'Notes on Photography \& Accident', 89

49 André Breton, 'Avant-dire (dépêche retardée)' (1962), in Nadja, Paris, 1965, 6.

50 Mary Ann Doane, 'Notes from the Field: Contingency,' Art Bulletin, 94: 3, September 2012, 348.

51 Doane, 'Notes from the Field', 348.

52 Mary Ann Doane, The Emergence of Cinematic Time: Modernity, Contingency, the Archive, Cambridge, 2002, 4.

53 Jonathan Crary, 24/7: Late Capitalism and the Ends of Sleep, London, 2013, 9. The uneasiness of the body's relation to clock time was explored in an exhibition curated by Susan Morris, A Day's Work, SKK, Soest, Germany, 
January-April 2019. See also her introductory essay to the catalogue, 'A Day's Work', 20-50. http://susanmorris.com/wp-content/ uploads/2019/09/ADW_SM-INTRO-WEB.pdf. The catalogue also contains essays by Iversen and Michael Newman.

54 In her PhD dissertation, Morris cited an article by Jörg Heiser, 'Emotional Rescue', Frieze, 71, November 2002, 71-75. It is about the work of Bas Jan Ader who, Heiser argued, 'invests the Conceptual with what appears to be its antithesis'. See Susan Morris, On the Blank: Photography, Writing, Drawing, PhD dissertation, University of the Arts. London, 2006, https://ualresearchonline.arts.ac.uk/id/ eprint/2309/13/Susan\%20Morris\%20PhD.pdf.

55 Briony Fer, 'Kafka’s Ear', in Susan Morris: Sontag Montag, ed. Deirdre O’Dwyer (exh. cat.), London, 2009, 31. This catalogue also includes essays by Iversen and Ed Krčma. See also the catalogue of a solo exhibition, Susan Morris: Self Moderation, with essays by Briony Fer and Sadie Plant, Kunsthaus Centre d'Art Pasquart, Biel, 2016.

56 Morris borrows this notion from Marcel Proust's 'The Intermittences of the Heart', a section heading, in Sodom and Gomorrah, Vol. 4 of In Search of Lost Time.

57 This is the line of enquiry pursued by Michael Newman in 'Decapitations: The Portrait, the Anti-portrait... and what comes after?', in Anti-Portraiture: Challenging the Limits of the Portrait, ed. Fiona Johnston and Kirstie Imber, London, 2020, 25-68.

58 Susan Morris, 'Drawing in the Dark,' Tate Papers, np. https://www.tate. org.uk/research/publications/tate-papers/18/drawing-in-the-dark.

59 This information can be found in her artist's book, Susan Morris, Sun Dial: Night Watch Tapestry Dossier, 2015.

60 See Russell Foster, 'Take a Survey Comparing the Sleeping Habits of Germans and Britons', The Guardian, 27 April 2012, available at http:// www.theguardian.com/science/blog/2012/apr/27/survey-sleepinghabits-germans-britons. Professor Foster's laboratory in Oxford provided Morris with the Actiwatches and the technical assistance with downloading the data.

61 Morris, in email correspondence with the author, 28 November, 2020.

62 Morris, Sun Dial: Night Watch, http://susanmorris.com/sun-dial-about

63 See Morris's short text on the Penguin (or Pelican) Freud Library at the Westminster Reference Library. http://susanmorris.com/wp-content/ uploads/2013/06/PENGUIN-FREUD_FINAL.pdf.

64 Davey has also made use of receipts as a form of automatic diary. Her Newspaper, Coffee (Receipts) II, 2015-16, takes the form of twelve analogue photographs of purchase receipts for newspapers, coffee and records that she took in the early 1990s. These were scanned and colorized by computer, folded and sent through the post in 2016 and then arranged in a grid.

65 Morris, Artist's statement for the exhibition 'Whisper Down the Lane', a group exhibition at UIC College of Architecture and the Arts, Chicago, 2013. http://susanmorris.com/whisper-artist-statement/.

66 Morris, email correspondence with author. The tapestry commission was funded by a Wellcome Trust Arts Award with additional support from the NIHR Biomedical Research Centre, Oxford, the KW Nuffield Laboratory of Ophthalmology, University of Oxford and the Oxford Radcliffe Hospitals NHS Trust. http://susanmorris.com/publications/.

67 'Artists Pick Artists: Susan Morris', in Hyperallergic, 17 April 2015, https://hyperallergic.com/199012/artists-pick-artists-susan-morris/.

68 See Hannah Arendt's discussion of this topic in the 'Introduction' to Walter Benjamin, Illuminations, Fontana, 1977, 38-51.

69 Barthes, Roland Barthes by Roland Barthes (1975), trans. Richard Howard, New York, 1977, 150.

70 Barthes, 'Pierre Loti', New Critical Essays, trans. Richard Howard, Berkeley, 1990, 108.

71 Jacques Lacan, The Four Fundamental Concepts of Psycho-analysis, ed. Jacques-Alain Miller, trans. Alan Sheridan, London, 1977, 114. This account compresses a long story. See Ed Krčma, 'Lightning and Rain: Phenomenology, Psychoanalysis and Matisse's Hand', Tate Papers, 18, October 2012, np. The article includes a discussion of the Lacanian underpinning of Mary Kelly's and Susan Morris's work. This issue of Tate Papers contains a cluster of papers on the theme of Involuntary Drawing, including Iversen, 'Index, Diagram, Graphic Trace' and Morris, 'Drawing in the Dark', https://www.tate.org.uk/research/ publications/tate-papers/18.

72 Lacan, The Four Fundamental Concepts, 114
73 Gallery information for exhibition of work by Susan Morris and Mathew Hale, Our Period, London, 2007, http://susanmorris.com/ourperiod-gallery-information/.

74 Morris, email correspondence with the author, 14 April 2017.

75 Morris, 'Inarticulations', Public Lecture, HdK, Zürich, Switzerland, 2017. Available at http://susanmorris.com/resources-links/.

76 Roland Barthes, 'The Death of the Author', 146.

77 W. G. Sebald, The Rings of Saturn, trans. Michael Hulse, London, 1998, 272, 286 .

78 The metaphor of letting things fall has been taken up by the theorist of photography, Peter Geimer, who observed that beyond photographic agency, 'there is also a dimension of the unforeseen. A photograph is, in this respect, also an occurrence: something in the image occurs or something falls into the image.' Peter Geimer, 'Notes from the Field: Contingency', Art Bulletin, 94:3, September 2012, 351.

79 Morris, 'Diary as Novel: The Writing of the Neutral?', Lifework Symposium, UCL, London, 2017. Unpublished paper.

80 Ann Banfield, Unspeakable Sentences: Narration and Representation in the Language of Fiction, London, 1982. See also, Banfield, 'L'imparfait de l'objectif: The Imperfect of the Object Glass', Camera Obscura, 3: 24, September 1990, 64-87. Special issue on 'Unspeakable Images'.

81 Susan Morris, On the Blank, 27, https://ualresearchonline.arts.ac.uk/id/ eprint/2309/.

82 Woolf, The Waves, London, 2000, 148

83 Morris, 'Inarticulations'.

84 See Morris's website: 'Diary Project': http://susanmorris.com/inprogress/.

85 See Eric L. Santner, On Creaturely Life: Rilke, Benjamin, Sebald, Chicago, 2006.

86 Kitnick, 'I, etcetera', 61.

87 Virginia Woolf, 'A Sketch of the Past', in Moments of Being: Autobiographical Writings, ed. Jeanne Schulkind, introduced by Hermione Lee, London, 2002, 84, 90, 85.

88 Virginia Woolf, 'A Sketch of the Past', 92-93.

89 Woolf, 'A Sketch of the Past', 84. Davey once remarked that accidently finding a solution to a particular artistic problem was 'like I had been anointed by some kind of rapturous illumination'. In 'Davey interviewed by Adam Szymczyk', 142

90 Morris, 'Inarticulations'.

91 See Morris's Instagram, a series of short videos posted on the Instagram account of Kunsthaus Centre d'Art Pasquart, Switzerland, as part of their artist@home 'takeover', during the Covid-19 lockdown. On 3 May 2020, over the course of twenty-four hours, Morris posted every hour on the hour. These separate posts have now been made into a film: https://vimeo.com/422379527.

There is also a version called RECORD. TRANSCRIBE. POST. that includes the Instagram captions: https://www.bc.show/work/sm24h. The writer Lynne Tillman posted on Instagram, @tillman_glossitis, a series of long one-sentence diary entries interspersed with snaps of her domestic interior with cat, views out of windows and shots of the TV screen. White Cube Gallery and the Hirshhorn Museum, Washington, DC commissioned numerous short films resembling informal diary entries by artists documenting their activities in quarantine.

92 See Baker, 'The Absent Photograph' for a discussion of Davey and the artist as receiver. 


\section{The Diaristic Mode in}

Contemporary Art after

\section{Barthes}

\section{Margaret Iversen}

The rise of the diaristic mode in contemporary art might seem like the return of the dead author in a particularly self-absorbed frame of mind. Yet the diary is a form of writing that relinquishes authorial control to the passing moods and contingencies of the day. The diarist writes hastily, automatically, involuntarily, thereby giving access to insights unavailable to deliberation. An account of Roland Barthes's Mourning Diary, 2009, and his reflections on the diary as a form of writing serve to introduce the diaristic work of two contemporary artists, Moyra Davey and Susan Morris. Their work is directly informed by Barthes's and others' experiments with a mode of address that is intimate, but also decentred and fragmentary.

Margaret Iversen is Professor Emerita at the University of Essex. Her books include: Alois Riegl: Art History and Theory (MIT Press, 2003); Beyond Pleasure: Freud, Lacan, Barthes (Penn State University Press, 2007); Photography, Trace and Trauma (The University of Chicago Press, 2017); and Writing Art History (with Stephen Melville; The University of Chicago Press, 2010). She edited a special issue of Art History, 'Photography after Conceptual Art', and another for Critical Inquiry, 'Agency and Automatism: Photography and Art since the Sixties', both with Diarmuid Costello. She also edited the Documents of Contemporary Art volume, Chance. 